\title{
STAMBØGER FRA TIDEN 1650-1750 I DET KONGELIGE BIBLIOTEK
}

\author{
$\mathrm{AF}$ \\ Vello HelK
}

$I^{2}$ de nærmest foregående bind af $\mathrm{F}$ \& $\mathrm{F}$ har jeg behandlet stambøgerne i Det kgl. Bibliotek frem til ${ }_{1} 650$. Navnlig fra begyndelsen af $1600-t a l l e t$ findes der mange stamboger i bibliotekets samlinger, og en del af disse fortsættes efter 1650 , nemlig hele $17 \mathrm{i}$ det forste tiår, mens kun tre af dem går endnu langere, deraf én ud over 1670 . I det følgende behandles stambogerne fra tiden $165^{I-1750}$, en periode som er kendetegnet ved nedgang, stilstand og en ny opgang henimod slutningen. Det var også en tid med langvarige krigsperioder, som skabte usikkerhed og afbrød de sædvanlige rejseruter. For Danmarks vedkommende kan nævnes KarlGustav-krigene $1657-60$, den skånske krig $1675-79$ og den store nordiske krig I 700-2 I, som alle havde eller var udløbere af krige uden for Norden. Det ovrige Europa hærgedes ligeledes af konflikter: $\mathrm{i}$ begyndelsen af perioden navnlig mellem Nederlandene og England, og dertil kom den pfalziske arvefølgekrig $1688-97$, den spanske arvefolgekrig $\mathrm{I} 7 \mathrm{I}-\mathrm{I} 3 \mathrm{og}$ de schlesiske krige $174^{\circ-42}$ og $1744-45$, for blot at næune nogle af de storste urokomplekser.

Talmæssigt er ejere af 80 selvstændige stamboger fra denne periode (deraf 46 fra for 1700 ) fordelt med 16 fra Danmark, 23 fra hertugdommerne og 4I fra udlandet. Af de sidste har $\operatorname{dog} 6$ slået sig ned i det danske monarki. Dertil kommer to danske adelsdamers stambøger, som er fortsat inden for slægten, og det samme er tilfeldet med yderligere en dansk og to slesvig-holstenske stambøger, mens to udenlandske er fortsat fra den sidstbehandlede periode med nye ejere. Ejere af blade og stambogsfragmenter fordeler sig med en dansk og to slesvigere, mens 12 har tilhørt udlændinge. Det samlede antal stambogsejere er 102.

Næsten tre fjerdedele af de selvstændige stamboger fra denne periode kommer fra samlinger anlagt af det $\mathrm{r} 8$. århundredes navnkundige sam- 
lere. Førstepladsen indtages som sædvanlig af Otto Thott med 39 numre, deraf har 26 tidligere tilhørt C. F. Temler. O. H. Moller er repræsenteret med I7 stambøger, mens 3 stammer fra Abraham Kalls samling.

Stambøgerne, som endnu i det 17 . århundrede havde en ret omfattende geografisk spredning, blev efterhånden begrænset til lande nord for Alperne, navnlig Tyskland, og indførslerne fra England og Frankrig er sjældnere. Således har mindst 44 ejere besøgt Jena, 34 Leipzig, 32 Halle og $3 \mathrm{I}$ Wittenberg, mens 16 stambøger har indførsler fra Nederlandene, 9 fra England og 4 fra Paris. Kun 3 stambøger har vidnesbyrd om et besøg i Italien, alle fra de forste årtier (Joh. Holtzkampf 1652 ,

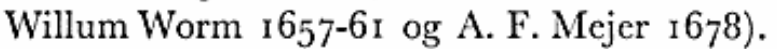

Stambogsskikken synes aldrig at have vundet særlig stor udbredelse ved Københavns universitet. Adskillige begynder deres stambøger med afskedshilsener efter studier her, men de er som regel skrevet af professorer og andre fremtrædende folk, kun yderst sjældent af studickammerater. Dette synes ikke alene at gælde danske, men i lige så høj grad de udenlandske besøgendes stambøger. I modsxtning hertil er indførsler ved de tyske universiteter for en stor del gjort af andre studenter.

I 1665 oprettedes universitetet i Kiel, hvor studenter fra hertugdommerne kunne starte deres studier, men det har tilsyneladende varet noget, inden stambogsskikken fandt fodfæste ved det nye universitet. Det hanger muligvis sammen med den omstændighed, at universitetets begyndelse faldt sammen med en nedgangsperiode for stambogerne. Ligesom i København domineres indførsler fra Kiel et godt stykke ind i I 7ootallet af professorer og andre lærde. Ofte begyndes stambogen forst efter at den pågxldende student har forladt Kiel (August Giese, Stephan Jebsen, Joh. Steinhammer, Abraham Kall og Gotth. Joh. Zwergius). Fra I 720rne får stambøger fra ophold $\mathrm{i}$ Kiel $\mathrm{en}$ bredere navnekreds og herefter de samme kendetegn, som karakteriserer indførsler ved de store tyske universiteter, navnlig Jena og senere også Göttingen, med stadig flere studenternavne og et djærvere sprog. Ved siden af de enkelte nationer opstod der henimod midten af i 7oo-tallet hemmelige sammenslutninger, som begynder at sætte deres præg på stambøgerne; ved siden af frimurerårstal o.l. optræder efterhånden mange hemmelige symboler og tegn.

Ved siden af studenterstambøger dukker der andre stambøger op, som får en vis udbredelse. Allerede tidligere plejede adelsdamer at fore stambøger med mindre geografisk spredning. Nu træder adelen i baggrunden og andre kommer til. Tendensen til at anlægge stambøger til brug for ejerens familie- og vennekreds blev yderligere forstærket i i 700 -tallet. 


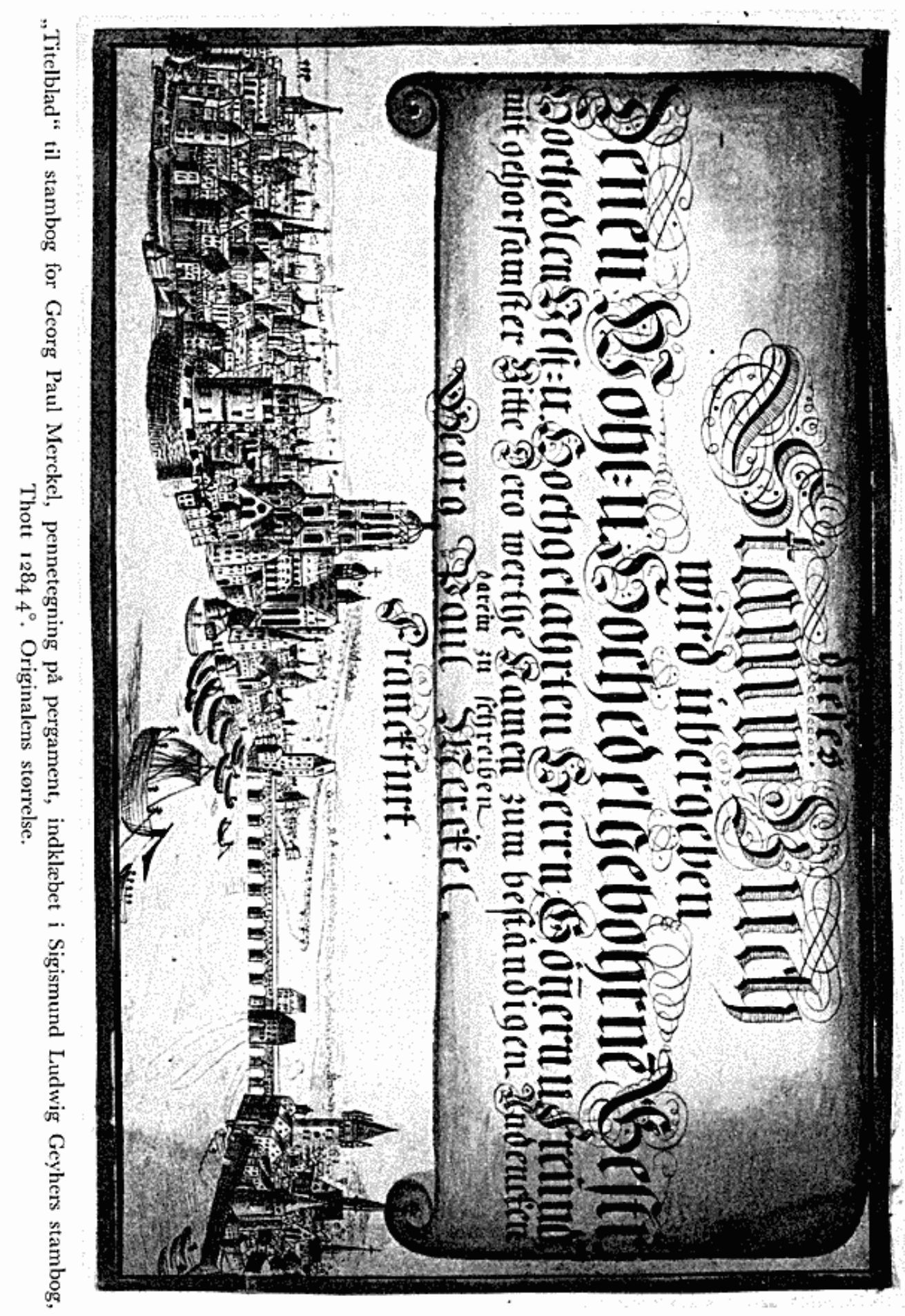


Stadig flere stambogsejere findes uden for de egentlige studenters kreds: kunstnere, boghandlere, håndværkere o.a., der med større eller mindre held forsøger at efterligne denne skik. Mens skikken stadig skulle sikre erindringen om moder med kendte personer og dyrkelse af venskabet, kunne andre aspekter trade stærkere ind i billedet. Således findes blandt de foreliggende stambøger et par stykker, som helt eller delvis har fungeret som almisscindsamlingsboger (Michael Christophori, Hans Gentzmer).

Ved de stambøger, som benyttedes på udenlandsrejser, kan man som regel gå ud fra, at ejeren har varet i den pågæeldende by den dag, indførslen er dateret. Ved korte indførsler må det antages, at ejeren har opholdt sig i samme hus, men ellers kunne stambogerne vandre fra hånd til hånd. Især når det gjaldt de kunstfærdige illustrationer, må det formodes, at bogerne blev lånt ud, således at dette arbcjde kunne udfores. Allerede tidligt kan det konstateres, at der er afsat plads til våbentegninger, som ikke er blevet fuldført; måske havde kunstneren ikke tid, måske skulle ejeren videre på sin rejse. Det er også muligt, at kammerater og bekendte kunne låne ens stambog, både for at lade sig imponere og for at få inspiration. Men således kunne disse bøger let komme på afveje. Måske ligger heri noget af forklaringen på, at enkelte stambøger synes afbrudt midt i en rejse, men der kan naturligvis også peges på andre muligheder såsom glemsomhed, tyveri o.l.

Mens de fleste stambogsejere på titelbladet ikke praciserer, hvordan stambogen egentlig fungerer, idet den som regel kun bliver tilegnet venner og velyndere, der anmodes om at skrive deres navne, formulerer den senere Moltrup-præst Gotthard Johan Zwergius tydeligt formålet i et indledningsvers, skrevet kort efter hans immatrikulation i Jena i maj I733. 'Salinen' i fjerde verslinie er floden Saale:

Hochwehrte, die Ihr mich schon längst im Kiel-Athen

In Eurer Freude Zahl unwürdig aufgenommen!

Und Ihr Geehrteste, die ich zuerst gesehn, Nachdem ich an den Strand Salinens angekommen!

Euch send' ich dieses Buch. Schreibt Eure Nahmen drein

So kan von Eurer Huld mein Stamm-Buch Zeuge seyn.

Stambøgerne er ofte en del af familietraditionen, som fortsættes gennem flere slægtled. Der er således bevaret to stambøger efter oldforskeren Ole Worm, og både hans søn og sønneson er repræsenteret i Kgl. Bibl.s samlinger med deres egne stambøger. Der kan nævnes tilsvarende eks- 
empler med tre stambøger, hver for sin generation, således inden for familien Sass i Haderslev og Assens og familien Schmollius i Regensburg. Med to generationer er i den foregående periode familierne Bartholin og Fuiren representeret, og begge perioder forbindes af stamboger fra familierne Bornemann, Giese og Paulli. Familien Kall har to generationers stambøger inden for den her behandlede periode, og skikken fortsættes efter $175^{\circ}$ med endnu et led.

I andre tilfælde kunne samme stambog vandre inden for familien, fra slægtled til slægtled. Således fik Johannes Jebsen sin svigerfader Stephan Klotz' stambog og overlod den senere til sin son Stephan Jebsen. Arven fra fader til søn er den almindeligste, som f. eks. inden for familien Jessen, men stambogen kunne også overgå fra moder til datter (f.eks. fra Elisabeth Ulfeldt til Lisbeth Friis). Der er dog i disse tilfælde altid tale om et klart afgrænset ejerskifte. Det kunne også foregå på den måde, at ejeren udlånte sin stambog til en anden, der skulle til et udenlandsk universitet. F.eks. overlod sognepræsten i Starup Jacob Caspergaard sin stambog med indforsler fra studietiden i Nederlandene ${ }_{16} 5_{2}$ til August Friedrich Jani fra Glückstadt, der videreforte den under sine studier i Leipzig og Halle ${ }_{16} 6_{3}$ og senere (1675) i Wittenberg, hvorefter bogen blev afleveret til den oprindelige ejer og fortsat af denne. Ved indforsler under låneperioden navnes ofte, at disse er hilsener til Caspergaard, skrevet efter anmodning af Jani.

Endnu mere indviklet bliver forholdet, når ejeren rejser til udlandet og lader sin stambog cirkulere blandt hjemmeværende venner og bekendte, som Terkel Klevenfeldt gjorde $\mathrm{I} 74^{2}$, da han befandt sig i Nederlandene og Frankrig, $\left.{ }^{1}\right)$ mens hans stambog med hilsener til den fraværende vandrede fra hånd til hånd $\mathrm{i}$ København, dog kun i nogle måneder. Det er muligt, at ejerens fravar ikke har inspireret til en længere fortsættelse. Det samme forhold træder endnu tydeligere frem ved de geografisk begrænsede stamboger: de kunne vandre i en vennekreds, og indførslerne kan ikke benyttes som bevis på ejerens tilstedeværelse på et givet tidspunkt.

Der er et forholdsvis stort antal anonyme stambogsejere, hvilket skyldes den omstandighed, at det efterhånden går af mode at navne ejerens navn ved de enkelte indforsler. Såvel fyrstelige som andre højtstående personer, derunder universitetsprofessorer, har næsten altid undladt det, vel overvejende af praktiske hensyn, da de jo skulle skrive i mange stambøger, som ofte blev præsenteret på én gang, således at det ikke altid var let at finde ud af, hvem den bog tilhorte, som de lige det ojeblik skrev i. Men nære venner og studiekammerater plejede at anføre ejerens navn 
med alle de gængse titler og hædrende titulaturer. Fra midten af I6ootallet spores der imidlertid en tendens til at udelade navnet og benævne ejeren blot som "hr. ejer" med forskellige hædrende tilføjelser, eller kun "kære ven", og hvis titelbladet mangler, kan en identifikation af ejeren ofte være vanskelig, idet man de sjældne gange navnet nævnes som regel nøjedes med efternavnet. Det er lettere at fastslå, hvor den pågxldende kom fra, idet hans landsmænd sørgede for at understrege dette forhold, og ligeledes nævnes studieretningen hyppigere. Man var „ven “ og „,broder" og undlod ikke at nævne det, mens navnet blev anset for overflødigt.

Stamboger fra Danmark og hertugdommerne. Fra midten af i6oo-tallet ebber det ud med de danskes udenlandsrejser, og endnu tydeligere er tilbagegangen ved stambøgerne. De danske stambøger fra den anden halvdel af I6oo-tallet, hvis ejere har varet i udlandet, er alle fort inden for den forste snes år. Derefter indtræder en stilstand, som varer over et halvt århundrede, inden Willum Worms (d. I 737) stambog med indførsler fra hans udenlandsrejse I 72 I-24 synes at indlede en ny udvikling, som tager fart i i 73 orne, da vi igen moder flere danske stambøger, men hverken antallet af besøg ved udenlandske universiteter eller antallet af bevarede stambøger kan herefter måle sig med de tilsvarende tal fra SlesvigHolsten. Nedenfor gennemgås summarisk de danske og de slesvig-holstenske stambøger. Først behandles studenterstambøgerne, derefter kommer de øvrige: adelsdamer, kunstnere og andre.

I marts 16 $_{5}$ I tog Peder Christophersen Bremermann, søn af den islandske købmand Christopher Bremermann, afsked med sine larere i København, der skrev deres hilsener i hans nyanlagte stambog, som blev fortsat under hans videre studier i Wittenberg, som synes at være afsluttet 1653 . Hans videre skabne er ukendt.

De første indførsler i Willum Worms (d. 1 704) stambog er fra 1652 , da han havde fået lejlighed til at ledsage Erik Rosenkrantz og Peder Reedtz på deres ambassade til England. Han tog da afsked med sine lærere, deriblandt hans privatpræceptor Thomas Bartholin og fader Ole Worm. Senere blev bogen fortsat på vidtløftige studierejser, påbegyndt $1653 \mathrm{og}$ fortsat gennem ti år, kun afbrudt af et ophold hjemme 1655 , men desværre indeholder den kun ret få navne fra den tid, således fra Padova Johan Rhode (31.8.1657) og fra Mantova lægerne Petrus og Sebastian a Castro (15. og $21 \cdot 5 \cdot 166 \mathrm{I}) .^{2}$ )

Universitetsboghandler Joachim Moltkes son Johan Moltke påbegyndte I653 efter studier ved Københavns universitet en udenlandsrejse, som i de næste seks år bragte ham vidt omkring. Opholdsstederne kan bestem- 
mes ved hjælp af hans stambog. I den første periode besøgte han universitetsbyerne Rostock og Greifswald. Efter et ophold hjemme drog han atter ud, over Rostock, Giessen, Heidelberg til Wittenberg og Praha, derefter til Tübingen og Strassburg, videre over Amsterdam til England $o g$ derfra til Paris, alt imens Danmark befandt sig i krig med Sverige. I 1659 var han atter i Rostock, hvorfra hans familic stammede, og derfra er også de sidste navne fra sommeren I66r dateret. Samme år blev han optaget i sin faders boghandel, men både faderen og han selv døde tre år efter, hvorefter forretningen gik til grunde $\mathrm{i}$ arvestridigheder. Fra det omfattende persongalleri i hans stambog kan nævnes barokdigteren Georg Philipp Harsdörffer i Nürnberg (20.2.1658).

Ligesom begge de foregående studerede rådmandssønnen fens Wandal fra Ribe under Karl-Gustav-krigene i udlandet, i Tyskland og i Nederlandene. Han var i april ${ }_{1} 656$ blevet immatrikuleret i Rostock, men stambogen begynder forst i marts 1657 , da han foretog en rejse til Greifswald. I april forlod han Rostock med Wittenberg som mål, hvor han blev indskrevet $\mathrm{i}$ slutningen af måneden. Efter godt to års studier gik rejsen videre til Franeker i Holland, hvor han blev indskrevet $\mathrm{i}$ oktober 1658. Forinden havde han i Haag besøgt den danske resident Peder Charisius. Året efter kom han også til Groningen, og de sidste navne er fra april 1659 fra Franeker, inden han rejste hjem til Ribe, hvor han allerede samme år døde af pest. ${ }^{3}$ )

I 1663 anlagde Christian Paulli, søn af kgl. livlage Simon Paulli, en stambog, hvori han det folgende år i København samlede flere gæstende fyrsters og diplomaters navnetrak, dog er der også ct par navne fra et ophold i april 1664 i Sorø. Blandt navnene er også de to jesuitter, der virkede som katolske kapellaner ved fremmede gesandtskaber i byen, nemlig Heinrich Mühlmann, der 25.4.1665 skrev sin ordens valgsprog „Omnia ad majorem Dei gloriam" og hans efterfølger Heinrich Kirchner med en hilsen af 3.12.1667. Desuden kan nævnes Valerio Maccioni, der af paven blev udnæunt til apostolsk vikar i den nordiske mission og $\mathrm{i}$ øvrigt forsøgte at få medlemmer af det danske kongehus til at konvertere. I foråret 1669 begav Christian Paulli sig til Helmstedt, og fra denne by stammer de sidste indførsler. Ejeren døde 1679 i Paris.

Den senere deputeret i Generalkommissariatet Balthasar Seckmann, søn af Københavns borgmester af samme navn, har efterladt sig en stambog med nogle få indførsler, hovedsagelig fra Strassburg og Leiden 1669-70.

Heller ikke hofretsassessoren og digteren Willum Worms stambog indeholder mange indførsler. De fleste er dateret 1721 i Leipzig, hvor han synes at have opholdt sig i nogen tid. Samme efterår rejste han over 
Halle og Frankfurt a. M. til Rotterdam, hvor han var i maj I 722 . I i 723 blev han assessor i Hofretten, men synes ifølge stambogen $\mathrm{i}$ begyndelsen af $\mathrm{i} 724$ at have været $\mathrm{i}$ Paris. Endelig har stambogen været $\mathrm{i}$ brug en enkelt gang I 729 i København. Ejeren skal have varet model for Holbergs "Jean de France“ ( I 722), og med denne tradition stemmer, at så godt som alle indforsler $i$ hans stambog, uanset de skrivendes nationalitet, er på fransk. Den eneste undtagelse er en indførsel, som samtidig findes på italiensk.

Lægesønnen Frederik von Buchwald fra Kobenhavn studerede først teologi, men skiftede dog senere over til medicin og blev en dygtig fødselslage. Hans stambog indeholder vidnesbyrd om hans studier i Tyskland, navnlig fra Jena, Halle og Rostock i årene $1733-35$.

Jorgen Leth fra Storehedinge rejste ud ${ }_{1} 736$ og studerede et par år $\mathrm{i}$ Jena og Halle. Hans stambog fra denne rejse er pietistisk præget, og pietismen har også kendetegnet hans senere embedsførelse som sognepræst i Dalum.

Jens Henriksen Schou, præstesøn fra Sal i Viborg amt, anlagde en stambog ved sin afsked fra Halle i marts-april ${ }_{1742}$. Den indledes med hans levnedsløb fra hans fødsel til 1737 . De fleste navne er studenter fra det dansk-norske monarki i Halle. Stambogen har også været i brug på hjemvejen og afsluttes i april I 742 i Lübeck.

Da prastesonnen Niels Randulf With fra Slagelse I 742 blev teologisk kandidat $\mathrm{i}$ København, tog han afsked med sine lerere og venner, såvel i København som i Slagelse. Deres navne udgør grundstammen i hans stambog, som blev fortsat under studicr i Halle og Jena. Stambogen afspejler ligeledes ejerens rejser til andre sachsiske universitetsbyer og blev fortsat efter hjemkomsten 1745 , forst i Broager og senere på Als, hvor Christian Carl Ludvig, en neger fra Afrika, er det sidste navn. Året efter blev With ansat i Tårnby på Amager, hvor han døde som sognepræst.

Af studenterstambøger fra hertugdømmerne har den tidligste tilhørt prastesønnen Jacob Caspergaard fra Vonsbæk, der anlagde den $165_{2}$ efter nogen tids studier i Franeker. ${ }^{4}$ ) Den blev flittigt brugt på hans rejse i Nederlandene inden hans hjemvenden. Efter hans tiltreden af sognepræsteembedet i Starup hentedes stambogen kun frem ved specielle lejligheder. En indforsel 24.3.1665 beretter, at stambogen ti dage for var blevet reddet, da Nordborg slot gik op i luer. Bogen har desuden været udlånt til mag. August Friedrich Jani fra Glückstadt, der benyttede den under sine studier i Leipzig og Halle ${ }_{16} 6_{3}$ og senere (1675) i Wittenberg. Derefter benyttedes den kun enkelte gange, næsten frem til ejerens død, således indeholder den en indforsel af Peder Terpager i Ribe 22.2.1689, 
og det sidste navn er archidiakon Paul Nielsen Sass 6.4.169г i Haderslev. Gennem dennes barnebarn og efterfolger Christoffer Sass kom bogen til O. H. Moller.

Jurastudenten Foham Woldenberg fra Itzehoe begyndte sin stambog ved afskeden med Rostock i august ${ }_{1} 6_{52}$ og fortsatte på senere rejser, som forte ham forst til Königsberg og efter et kort ophold hjemme 1653 til Nederlandene med studier i Franeker ( $1653-54$ ) og påfolgende rejser over Amsterdam og Köln til Frankrig med ophold i Paris og Sedan ( $1655-57$ ). Derfra begav han sig i maj 1657 til London og var i juni tilbage i Nederlandene, hvor indforslerne slutter i Amsterdam.

Med en enkelt indførsel fra sit korte ophold i Rostock ${ }_{1} 656$ fik Cosmus Bornemann ${ }^{5}$ ) begyndt sin stambog, men forst efter sin deltagelse i krigen og fredsslutningen 1660 drog han atter afsted, ledsaget af afskedshilsener fra københavnske professorer. På vej til Nederlandene fulgtes han med det nederlandske gesandtskab, der havde været med ved fredsforhandlingerne i Oliva. Flere af dets medlemmer, således Wilhelm van Hare og Pieter de Huybert, har skrevet deres hilsener undervejs på skibet. I Nederlandene studerede Bornemann i Franeker, opholdt sig også i Groningen og Amsterdam, hvor han 2.6.166r modte den berømte pædagog Johann Amos Comenius. I samme by afsluttes stambogen i oktober I664. Efter hjemkomsten blev Bornemann professor ved Københavns universitet, 1684 borgmester og året efter tillige assessor i Højesteret.

Paul Jessen, søn af diakon Johannes Jessen i Bredsted, ${ }^{6}$ ) begyndte sin stambog ved skoleafslutningen i Flensborg ${ }_{16} 66$. Blandt de forste navne er rektor Johan Wigand, hos hvem han havde boet i to år. Året efter tog ejeren afsked med venner og familie i Bredsted, og også faderen onskede ham i den anledning held og lykke på rejsen. Dernæst synes han at have fortsat sin skolegang i Lüneburg (1658-59). I de folgende år studerede han i Leipzig, idet han også besøgte Jena, Halle og Wittenberg. I66o vendte han tilbage til hertugdommerne, og de sidste indforsler er fra april $\mathbf{I} 663$ i Bredsted. To år senere blev han diakon i Bordelum.

I prastefamilien Sass blev stambogsskikken fort videre af Paul Nielsen Sass, søn af sogneprest Niels Sass i Assens. ${ }^{7}$ ) Den unge mand anlagde sin stambog ved afskeden med Wittenberg 1666 og benyttede bogen flittigt under hjemturen. Samme efterår drog han over Odense til Kobenhavn, hvor han synes at have opholdt sig i nogen tid. I i667 vendte han tilbage til sin fedrene by Haderslev for at overtage en stilling som archidiakon ved domkirken, som han beholdt til sin død. Stambogen har også $\mathrm{i}$ de folgende år været fremme og er benyttet med jævne mellemrum frem til 1698 . Blandt dens navne i den sidste periode er Starup-presten Jacob 
Caspergaard, der har skrevet en hilsen under Sass' besøg hos ham I 5.3.I69I, en hilsen, som Sass gengældte tre uger senere. Som den tredic stambogsbesidder inden for slægten optrader hans søn Nicolaus Gottfred Sass, ${ }^{8}$ ) der begyndte med afskedshilsener fra Wittenberg, Jena og Leipzig I697 og fortsatte hjemme i Haderslev, hvor bl.a. faderen har skrevet en hilsen for afrejsen til København. Her har han hentet de sidste indførsler fra tiden frem til december 1700 , da han efter faderens dod vendte hjem for at overtage dennes stilling som archidiakon, som han beklædte til sin død.

Stephan Febsen $^{9}$ ) fortsatte sin faders og bedstefaders stambog under studier i Leipzig og Königsberg I670-75, senere hovedsagelig i Hamburg 1676-79 og under en rejse til Nederlandene og England r684. Den indledes af hans moder Catharina Jebsen i Rendsborg 28.3.1670 og afsluttes i Oxford 14.7.1684.

Stadssekretær i Husum August Giese havde en søn foachim, ${ }^{10}$ ) der fortsatte sin faders stambogstradition. Han begyndte i maj 1670 ved afskeden fra Lübeck og fortsatte under sine studier i Helmstedt I67I-75, afbrudt af et ophold i Altdorf ( $1673-74$ ).

Bernhard Lassaus fra Tønder ${ }^{11}$ ) har fort stambog i sin hjemby ${ }^{1} 673 \mathrm{og}$ derefter i Kiel. Den indeholder desuden vidnesbyrd om ejerens studier og ophold i Rostock (1675), Wittenberg, Leipzig og Helmstedt (1678). Flere af stambogens blade er dog gennem en senere ejer havnet andre steder, deriblandt en indforsel af Josua Schwartz i $168_{5}$, samme år da denne blev udnævnt til superintendent i Slesvig.

Peter Malmogius fra Flensborg ${ }^{12}$ ) anlagde sin stambog ved afrejsen fra gymnasiet i Danzig i foråret $169^{2}$. Senere er den benyttet under studier i Leipzig 1693 og på en rejse i marts-maj I694, som forte ham over Dresden til Altdorf og Nürnberg og videre til Wittenberg og Magdeburg, hvor stambogen slutter. Den indeholder et stort antal præster og lærere, som han har mødt undervejs, men overhovedet ingen landsmænd. Ejeren blev senere garnisonsprest og sluttede sine dage som sogneprest $\mathrm{i}$ Kropp.

Ret fattig på indforsler er også den stambog, som Manasse Monrad fra Ketting ${ }^{13}$ ) forte med sig under sine studier i Wittenberg, Jena og Halle I693-94. Kun én landsmand har fundet plads, nemlig magister Jacob Peter Stephani fra Garding, mens resten er fremmede professorer og præster. Ejeren blev senere præst på Sjælland.

Johan Steinhammer fra Slesvig ${ }^{14}$ ) blev allerede 1692 immatrikuleret i Kiel, men sin stambog påbegyndte han forst 1696 , da han rejste til Holland. Der opholdt han sig i nogen tid, virkede som præceptor, navnlig i Haarlem, og foretog 1697-98 en rejse til England. I efteråret I699 
vendte han tilbage til Slesvig. Senere har stambogen været i brug under en rejse $\mathrm{I}_{704}$ til Wittenberg, Leipzig og Halle. Samme år blev han kompastor og rektor i Frederiksstad, og stambogen er kun benyttet én gang senere, nemlig I 709 af en svensk student.

Abraham Kall fra Flensborg, ${ }^{15}$ ) senere præst i sin fodeby, har efterladt sig en stambog med navne fra sine studier i Halle 1702-og. Hans søn Johan Christian Kall, ${ }^{16}$ ) der var født, mens faderen 17I4 var pastor i Charlottenburg ved Berlin, vendte $173^{2}$ tilbage til samme egn og fortc ligeledes en stambog med mange indførsler fra Jena, hvor han blev indskrevet 3.5.I 732. Året efter kom også han til Halle. De fleste indførsler skyldes professorer og andre lærere. Bogen slutter $173^{8}$, da ejeren blev professor i orientalske sprog i København.

Conrad Wilmsen fra Slesvig ${ }^{17}$ ) anlagde sin stambog under studier i Kiel I 704-05, fortsatte i Rostock 1705 og i Jena I 706. Samme år vendte han tilbage til sin hjemstavn, hvor bogen slutter med et par indførsler i Slesvig 10.12.1 706 .

Friedrich Gabriel Schreiber fra Glückstadt tog afsked med sin hjemby i maj $1705 \mathrm{og}$ begav sig til Jena. Fra denne by stammer de fleste tilskrifter, hovedsagelig af slesvig-holstenske studiekammerater. Inden hjemrejsen I 708 besøgte Schreiber også Halle, Wittenberg og Berlin. Med en indforsel af Nicolaus Peter Sibbern, den senere slotsprest i Glückstadt, slutter bogen i ejerens hjemby 5.3.r 7 II

Præstesønnen Nicolaus Hoier fra Flensborg, senere diakon i sin hjemby ${ }^{18}$ ) havde en stambog med talrige navne, de fleste studiekammerater, omtrent halvdelen landsmænd, overvejende fra Jena I 7 I2-I 5 .

Christian August Lüders fra Grumtoft i Husby herred ${ }^{19}$ ) studerede først retsvidenskab i Wittenberg, hvor han i $7 \mathrm{I} 6$ fik de forste navne. De fleste hilsener er dog fra Jena og Leipzig, hvor han synes at have opholdt sig det følgende år, hvilket bevidnes af en række landsmænd. I I 718 var Lüders i Slesvig, og de resterende navne frem til i 72 I stammer fra denne by og Gottorp; deriblandt er der flere jurister, måske med tilknytning til hoffet.

Præstesønnen Nicolaus Bernhard Ambders ${ }^{20}$ ) påbegyndte sin stambogved afrejsen fra Greifswald - efter to års studier - i april I 726. Kort efter blev han immatrikuleret i Jena, hvor han ligeledes opholdt sig et par år. I april I 73I finder vi ham i København på vej til udlandet og I732-35 atter i Jena. I foråret $\mathrm{I} 737$ var han i Wien, hvor flere embedsmand ved det stedlige danske gesandtskab med legationssekretær Gerhard Ernst Frank de Frankenau i spidsen indskrev deres navne. I juli $\mathrm{I} 737$ var han i Paris, og stambogen slutter med en indforsel i Hannover 20.2.1 738. Af 
interessante hilsener bemærkes en fra professor Christian Nettelbladt i Greifswald 3.4.I 726 , ledsaget af et bibelcitat i runer.

Den senere russiske historieskriver Burchard Adam Sellius fra Tønder ${ }^{21}$ ) anlagde sin stambog under sine studier i Jena $1727 \mathrm{og}$ fortsatte i de følgende år også i Halle og på de hjemlige kanter, indtil han ${ }_{1} 73^{2}$ drog til Rusland, hvor han dode som grask-katolsk munk.

Den sencre sognepræst i Moltrup Gotthard Johan Zwergitus fra Tønder ${ }^{22}$ ) har de fleste indførsler fra sine studier i Jena $1733-35$, overvejende af landsmænd fra hertugdømmerne. I modsætning dertil indeholder den stambog, som den senere borgmester Fohan Lass fra Husum ${ }^{23}$ ) har efterladt sig, næsten udelukkende navne på professorer og andre høje herrer fra Halle og Jena 1741-42.

Johan Dankwart fra Husum ${ }^{24}$ ) anskaffede sig en stambog under studier i Jena ${ }_{1744}$ og den by blev hans faste opholdssted en årrække. Han studerede forst teologi og rejste sidst på året $\mathrm{I} 747 \mathrm{hjem}$ for at underkaste sig tcologisk eksamen, men allerede året efter finder vi ham i Jena, hvor han nu begyndte at studere retsvidenskab. Som jurist kan han følges gennem stambogen frem til september I 754, hvorefter alle spor forsvinder. Bogen indeholder et langt og broget navnegalleri, hovedparten af hans landsmænd fra hertugdommerne, som dengang i stort tal studerede i Jena.

Blandt ejere af de bevarede blade er foruden Jens Ebbesen Sack, senere sognepræst i Madum-Tim, der er representeret med et enkelt blad fra Francker $1652^{25}$ ) og Fr. Aug. Holmer fra Slesvig, ${ }^{26}$ ) der har et blad fra Jena 1674 , bevaret mange blade af Johan Adolph Axens ${ }^{27}$ ) stambog. Denne stammede ligeledes fra Slesvig, og efter sine studier i Kiel og Frankfurt a.d.O. har han varet på en rejse til Nederlandene og England, hvilket bevidnes af adskillige indforsler fra tiden $1692-97$.

Spindesiden er repræsenteret ved fire stambøger, hvoraf to har tilhørt adelsdamer. Den forste er Dorte Gjøes stambog, som fortsatte sin vandring gennem familien. Den gik nu fra Sophie Krabbe, der muligvis ved sit giftermål med Otte Marsvin - der for havde varet gift med en søster til stambogens anden ejer Sophie Brahe - var kommet i besiddelse af den, over til datteren Jytte Krag, der blev gift med Axel Sehested. ${ }^{28}$ ) De fleste indforsler er da også, efter at den nye ejerinde havde indledt sin del med en salme på 21 vers, skrevet ca. I695-99 på Noragergård, hvor familien hørte hjemme. Familien Sehested tegner sig i øvrigt for omtrent halvdelen af navnene.

En anden adelsdames stambog, som fortsatte i familien, var Elisabeth Ulfeldts, som blev overtaget af døtrene Sophie og Lisbeth Friis, ${ }^{29}$ ) idet den 


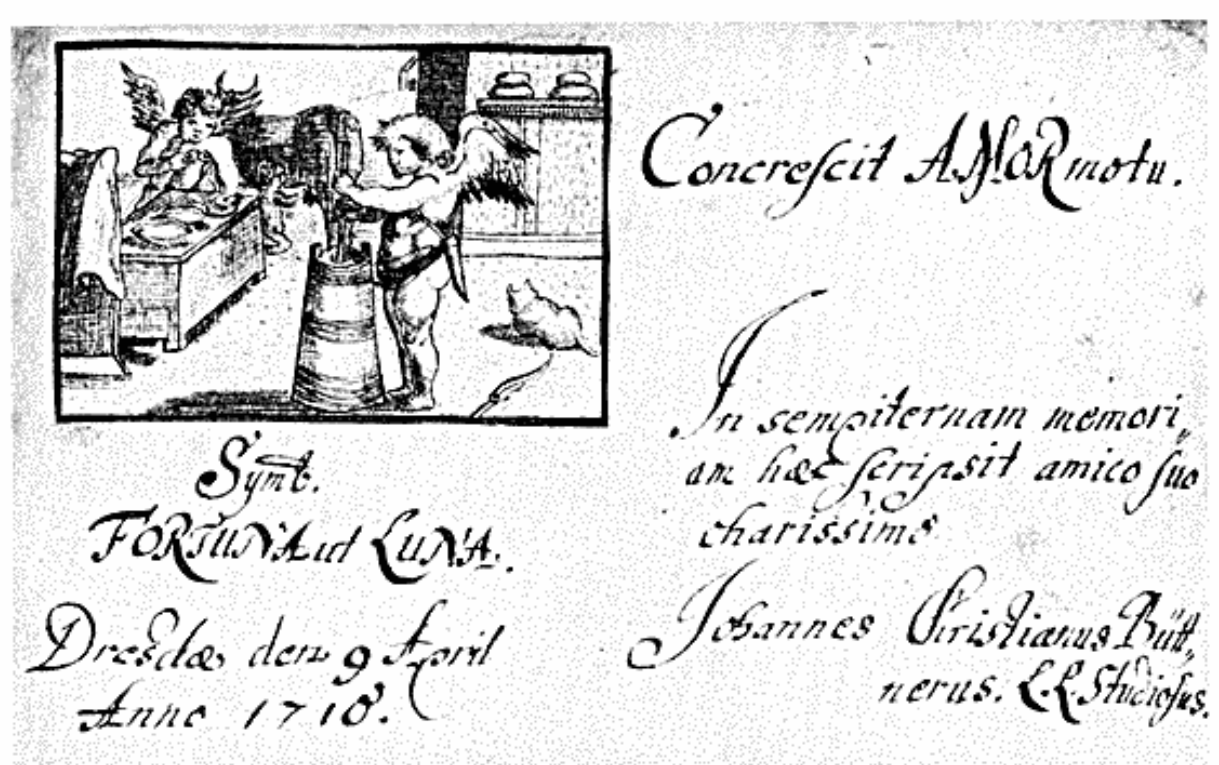

Indforsel i J. C. Dommers stambog af Johann Christian Büttner, dateret Dresden 9.4.1710. Sentenserne 'Concrescit Amor motu' og 'Fortuna ut luna': Amor styrkes ved bevægelse og Lykken er lunefuld. Thott $43^{6} 8^{\circ}$. Lidt formindsket.

sidste synes at have været den egentlige ejer, som nævnes i en lang række indforsler. Bogen indeholder mange tilskrifter, ikke alene fra talrige fynske herregårde, men også fra Sjælland og Lolland. Blandt de sidste er Leonore Christine i Maribo kloster 7.10.1694. Stambogen afsluttes i januar 1702 på Hvedholm.

Den tredie kvindelige stambogsejer fra midten af $\mathbf{z}$ 7oo-tallet representerer en helt anden type. Det drejer sig om den smukke kunstnerstambog, som er efterladt af fohanne Fosie, datter af kobberstikkeren Jacob Fosie og selv en habil kunstnerinde, der synes at have holdt en slags salon for sine kunstnervenner, elever og beundrere. Adskillige har skrevet deres overstrommende hyldest til hende, ofte ledsaget af en tegning eller et stik, andre nøjedes med en ren kunstnerisk udfoldelse, dog gerne signeret. I stambogen moder vi store navne som malerne C. G. Pilo og Joh. Fr. Wahl og kobberstikkeren J. M. Preisler, desuden kobberstikkerne Gustav de Lode og Michael Keyl, radereren P. Hoverbek og medailløren P. C. Winsløv. Der er desuden enkelte elever af Jacob Fosie, således sorenskriveren Chr. Otto Willars og kobberstikkerne P. J. Grønvold og H. J. Kirksteen. Blandt Johanne Fosies egne elever kan navnes kobberstikkeren F. C. Scholten, sekretæren i Tyske Kancelli Fr. Laub og sorenskriveren E. S. Resch. Flere af dem er dilettanter som f. eks. søofficeren Jens 
Reiersen. ${ }^{30}$ ) Stambogen afsluttes 3 I $.8 .175^{8}$, dagen for ejerindens giftermål, med en indførsel af forfatteren Chr. Flensborg.

$\mathrm{På}$ grænsen til den anden halvdel af århundredet ligger Maria Baack Hammerichs stambog, som udgores af en trykt andagtsbog med indskudte hvide blade, kun få gange benyttet til indførsler, ellers til familieoptegnelser.

En anden kunstnerstambog fra det danske monarki har tilhørt maleren Nicolai Christian Moritz, ${ }^{31}$ ) der anlagde den under et besøg i Danzig i sommeren 1702. Allerede ved juletid finder vi ham i København, hvor han opholdt sig de følgende år. Fra 1706 synes han at have taget ophold i London, hvor han endnu var seks år senere. Den sidste indforsel er fra Slesvig 1726 . Bogen indeholder en mangde skitser og tegninger af mere eller mindre kendte kunstnere, deriblandt Otto de Willarts og Balthasar Masius. Flere indklæbede tegninger bærer en ældre datering, således en af Hirschholm 1679. Den nyeste er dateret Tyberggård I 732, stambogsejerens dødsår.

Hos genealogen Terkel Klevenfeldt er hovedvægten lagt på det heraldiske - på våbentegninger, men hans stambog rummer dog også indforsler uden våben. Det hele er blevet til i forste halvdel af $\mathrm{I}_{742}$, da ejeren opholdt sig i Nederlandene. ${ }^{32}$ )

Nær beslægtet med ovennæunte Jørgen Leths stambog er den lille pietistiske bønnebog med ubeskrevne venstresider, som Bastian Gerhard Wessel har benyttet. Vi møder ejeren for første gang i juni $1740 \mathrm{O}$ Lauchstädt. Derfra rejste han til Danmark, men vendte I 74I tilbage til Halle. Året efter var han atter i Danmark, og i sommeren 1743 drog han over Haderslev og Altona til Wernigerode, Halle og Köthen. Samme efterår vendte han tilbage og opholdt sig fra nu af hovedsagelig i København og på Fredensborg. I efteråret $175^{\circ}$ rejste han til Trankebar, gjorde $\mathrm{i}$ begyndelsen af $175^{1}$ ophold ved Kap det Gode Håb og var i Trankebar i august-september samme år. Derefter afsluttes stambogen med indførsler fra København i efteråret 1753 . Indholdet røber intet om ejerens profession, heller ikke hans nationalitet er kendt. Hans tilknytning til de pietistiske kredse er tydelig, navnlig under opholdet i Wernigerode 1743, hvor en række medlemmer af den grevelige Stolbergske familie og flere missionærer, deriblandt Anton Heinrich Walbaum, skrev i stambogen. I København og navnlig på Fredensborg synes Wessel at have haft forbindelser med hoffets betjente af lavere rang, og det kunne tænkes, at han blev anvendt som budbærer. I Trankebar mødte han de stedlige missionærer: Ole Maderup, Joh. Chr. Wiedebrech, Joh. Balth. Kohlhoff o.a. Ingen indførsler henvender sig personligt til ejeren, man 
takker som regel blot Gud, med eller uden nærmere motivering. Wessels profession lader sig dog bestemme gennem journalen på det skib, som bragte ham til Trankebar, nemlig "Cron Princessen af Dannemarck", hvor han var påmønstret som skibskok. ${ }^{33}$ ) Skibet forliste på hjemvejen ved Sydafrika, men både Wessel og hans stambog blev reddet. ${ }^{34}$ )

To stambøger skiller sig ud fra andre, idet der her egentlig er tale om almisseindsamlingsbøger. Den første har tilhørt en præst ved navn Michael Chrislophori, antagelig fra Pommern, der synes at have mistet sit embede. I tiden $165^{2-53}$ drog han gennem Danmark, fra by til by og navnlig fra præstegård til præstegård, med en stambog, som indeholder over 300 indførsler fra det danske monarki, de fleste fra Jylland. Ved adskillige navne er der anført et pengebelob, en markering af rejsens og stambogens egentlige formål. Endnu tydeligere trader dette frem ved den bog, som Hans Gentzmer, der I664 var blevet afsat fra sit embede som præst' $\mathrm{i}$ Tandslet på Als, anlagde $1669 .{ }^{35}$ ) Den indledes ligefrem med en redegørelse for, at ejeren på grund af sygdom ikke længere kunne påtage sig arbejde og derfor i storste blufærdighed var nødt til at bede om en ringe skærv. Derefter følger en række indførsler næsten lige til ejerens død i januar 1683 , til dels med et tilføjet pengebeløb. Mange embedsbrødre har dog kviet sig ved at notere beløbet, men trøstens ord mangler sjaldent. Ved bibelcitater og ordsprog formanes ejeren til at tage sin skabne med fatning og også i modgang at bøje sig for Guds vilje. Bogen er indrettet således, at den udmærket kunne fungere som en indsamlingsliste, som kunne overlades til en anden person og så sendes fra sted til sted, og det fremgår da også af visse indførsler, at den pågxldende har sendt sin skærv.

Endvidere er der i alt seks stambøger, hvis ejere stammer fra andre lande, men har en så nær tilknytning til det danske monarki, at de må tages med under denne gruppe. Der er først Georg Pasch fra Danzig, der havde gennemrejst Tyskland (I684-87), Nederlandene (I687-88) og England (1688), med mange navne fra adskillige ærværdige universiteter i sin stambog, inden han 1689 kom til Kiel, hvor stambogen slutter i april samme år. Først i september blev han indskrevet i matriklen, og han forblev i Kiel resten af sin levetid som professor, sidst i teologi.

Fra Güstrow stammer Gustav Schrödter, hvis stambog, nærmest et poesialbum med lange digte, markerer hans studium og ophold i Wittenberg, hvor han blev indskrevet 30.4.1689 og opnåede magisterværdigheden 15.10.169i. Senere trådte han i dansk tjeneste, var fra 1698 legationspræst i Spanien og Frankrig, blev i 708 sognepræst i Süderau og virkede fra 17 I2 til sin død i Glückstadt. ${ }^{36}$ ) 
Johann Christian Stockmann fra Hildenstedt i Sachsen kom efter sine studicr i Halle, Jena og Leipzig ( 1716-2I) og ophold i forskellige tyske byer omkring 1726 til hertugdommerne. Efter nogle års forlob begav han sig til Kobenhavn, hvor han ses at vare endnu i740, samme år da han blev diakon i Drelsdorf og året efter sognepræst. ${ }^{37}$ ) Stambogen har siden da kun været fremme til benyttelse en enkelt gang, da den senere diplomat og udenrigsminister Adolph Siegfred v. d. Osten skrev en hilsen i Drelsdorf.

Da Johann Christoph Kleffel fra Tangermünde I 720 blev immatrikuleret i Wittenberg, anlagde han to stamboger. Den ene fortrinsvis beregnet til lærere og finere bekendte findes nu i Göteborg, ${ }^{38}$ ) mens den anden, trods mange fjernede blade med mere end dobbelt så omfattende navnegalleri som den første, har været forbeholdt en bredere kreds af venner og bekendte. De fleste navne er fra Wittenberg, men også ophold i Helmstedt (I 72 I), Leipzig (I 722-23), Hamburg og Lübeck (I725) kan tidsfestes. Fra juli i 725 har Kleffel opholdt sig i hertugdømmerne, således i Slesvig (I 725 og 1 1 27 ), Kiel (1727) og Tonning (I 739 og I 741 ). Han virkede som rektor i den sidstnæunte by ${ }^{39}$ )

Heinrich Daue, hvis stambog begynder under hans studier i Jena ${ }_{173} 7$, var fodt i Lübeck, men hans fader Hartvig havde under den store nordiske krig stået i dansk tjeneste, og til Danmark drog også hans tre sonner. Mens de to andre efter nogen tid atter gik til Lübeck, blev Heinrich i Danmark og opholdt sig en tid på Fyn, hvor han var regimentsauditor. Med et enkelt navn fra 1756 i København slutter bogen, hvis ejer senere blev herredsfoged i Nordslesvig. ${ }^{40}$ )

Christian Gottlob Mengel fra Schweidnitz i Schlesien begyndte sin stambog 1739 i Leipzig og Dresden, inden han året efter begav sig til København, hvor han forst var ansat hos boghandler Jacob Preuss. Da denne kort efter fallerede, fortsatte han som selvstandig, dog uden storre anseelse, og døde 1769 i stor fattigdom. Hans stambog indeholder nogle spredte indførsler fra hans tid i Kobenhavn, blandt andet af hans hustru Engel Margrethe Mengel. ${ }^{41}$ )

Nogle få danske stambøger fra denne periode befinder sig uden for Kgl. Bibl. I Rigsarkivet findes en stambog, som har varet benyttet af Fohan Sperling fra Odense under hans studier i Tübingen og Strassburg 1655-56. Landsarkivet for Norrejylland i Viborg har et fragment med fire indforsler $\mathrm{I} 68 \mathrm{I}$ fra Jena, en rest af Anders Knudsen Borbergs stambog.

Den senere landsdommer og historiske forfatter Peder Benzon Mylius foretog I 7IO-I I en rejse til de sachsiske universitetsbyer. Hans stambog fra rejsen er bevaret i Ronningesøgårds arkiv i Landsarkivet i Odense. 
Den antikvariske samling i Ribe har et album, som har tilhørt provinsialmedikus Ancher Anchersen og er benyttet hovedsagelig under hans studierejse til Leipzig, Halle og Strassburg I 728-30. Endvidere besidder Herlufsholm skoles bibliotek et rigt illustreret album, som har tilhørt Christoffer Woldike fra Helsingør og er blevet benyttet i tiden $\mathbf{1} 742-46$, foruden i København bl.a. i Halle, Leipzig og Kiel.

Mange stambøger fra hertugdømmerne er i tidens løb kommet til biblioteker, museer og arkiver i Slesvig-Holsten, de fleste stammer dog fra tiden efter $\mathbf{1} 75^{\circ}$. Fra tiden for har universitetsbiblioteket i Kiel stambøger for Johann Christoph Hennings fra Plön med indforsler hovedsagelig fra Jena $173 \mathrm{I}-36 \mathrm{og}$ for Heinrich Zeise fra Haderslev fra hans rejser og studier i Göttingen, Halle og København 1 737-4I. Det slesvig-holstenske landsbiblioteks ret omfattende samling indeholder bl.a. stambøger for Anders Ambders fra Westerland med de fleste indforsler fra Kiel $\mathbf{1}_{725}$, for Eberhard Weinmann fra Süderstapel fra hans studier i Jena I 734-36 og for Friedrich Reyher fra Kiel med navne fra Kiel og Jena 1 743-48. Endvidere kan nævnes stambogssamleren Olaus Heinrich Mollers eget album med indforsler hovedsagelig fra Jena og andre sachsiske byer $1734-47$, men også fra København og Flensborg frem til I $_{7} 65$. Det findes i stadsarkivet i Flensborg. ${ }^{42}$ )

Af stambøger med særlig tilknytning til Danmark i udenlandske samlinger må fremhæves Gollieb Schützes album i The British Library i London. Ejeren er født i Wernigerode, men flyttede 1738 med familien til Altona og blev senere dansk diplomat. Stambogen indeholder mange indforsler fra ejerens virke som hovmester for to unge grever af familien Schack i Sorø $174^{8-5} \mathrm{I}^{43}$ )

Udenlandske slamboger. I modsætning til de tidligere behandlede perioder, hvor Sydtyskland er forholdsvis stærkt repræsenteret, kommer de fleste ejere nu fra Nordtyskland. Denne tendens er ret tydelig i begyndelsen af i 7oo-tallet, hvor samtidig de fleste stambøger er ført under studier i Jena og Halle, i mindre grad i Wittenberg og Leipzig, med besog i omliggende byer. Så godt som alle hører hjemme i det tyske sprogområde. Kun i to tilfalde markeres et hjemsted udenfor. Det gælder således for Paulus Galli fra Ungarn, der $1655-56$ studerede i Wittenberg, men efter at have virket som protestantisk prest blev tvunget til at forlade sit hjemland. Som exulant vendte han $16_{74}$ tilbage til Sachsen med sin stambog fra studietiden som rejseledsager og vidne. Han besøgtc atter Wittenberg, drog videre til Hamburg og befandt sig i sommeren 1675 i Dresden, hvor han mødte adskillige skæbnefæller fra Ungarn. De sidste 
indforsler er fra samme efterår, da han var i Schlesien, hvor også flere ungarske protestanter havde søgt tilflugt.

Mere exotisk forekommer Peter Ayerschöttel, hvis hjemsted angives at være Recife del Pernambuco i Brasilien. I øvrigt betegnes han som „art. pict. stud.“, altså student i malerkunst, og har måske været en af dem, der tjente til livets ophold ved at udsmykke stamboger. Han har hovedsagelig opholdt sig i Altdorf og Nürnberg i tiden $1673-74$, senere også i Augsburg (1675) og Wien ( 1676 ). Han har haft forbindelser i universitetskredse, idet stambogen indledes af rektoren i Altdorf, Johann Conrad Dürr, og adskillige andre lærere og studenter gør ham følgeskab, men i den i øvrigt brogede skare findes tillige andre: malere, guldsmede, stenhuggere og parykmagere, hvis indforsler ofte ledsages af mere eller mindre originale kunstneriske udfoldelser, som det var almindeligt i en kunstners stambog. Familien Ayerschöttel hører i øvrigt hjemme i Nürnberg, og flere indførsler bekræfter et slægtskabsforhold. Samtidig betegnes ejeren af Joachim Giese fra Husum som landsmand og skolekammerat, må altså være beslægtet med eller måske ligefrem en søn af Christoph Ayerschöttel, der kom til Husum $1655 \cdot{ }^{44}$ ) Hans forbindelse med Brasilien har det ikke været muligt at få bekræftet, men måske er han født under familiens eventuelle ophold i Recife.

En enkelt stambog har været ejet af brødrene Paritius i fællesskab, og det fremgår yderligere af indførsler, at de har været malere. Den ene af dem har antagelig været den sachsisk-anhaltske hofmaler Christian facob Paritius, hvis initialer smykker bindet, og det er sikkert også ham, der har ejet et par andre stamboger, som gennem Temlers og Thotts samlinger ligeledes er kommet i Kgl. Bibl. ${ }^{45}$ )

Bortset fra dem, der slog sig ned i det danske monarki, har kun få af de udenlandske stambogsejere besøgt Danmark. I september i684 kom den senere sognepræst i Isernhagen og Celle Sigismund Hosmann ${ }^{46}$ ) efter en rejse, som havde fort ham rundt om Østersøen, over Königsberg, Østersøprovinserne, hvor han næsten to år havde virket som huslærer, og Sverige til København. Her afsluttede han sin stambog med indførsler af professorerne Hans Wandal og Ole Borch, den nybagte magister Hans Eriksen Mand fra Erø, der efter en militar karriere og deltagelse i den skånske krig kort efter blev præst $\mathrm{i}$ Vindeby, og endelig den tyske menigheds sogneprast Christian Brämer.

Da Georg Christian Kahrstädt, den senere superintendent i Dettum, ${ }^{47}$ ) der havde virket som informator ved det braunschweig-lüneburgske hof i Bevern, på vej til Sverige gjorde et kort ophold i København i februar r6g8, tidsfestes besøget ikke af lærde navne, men af F. J.v.d. Osten, til- 


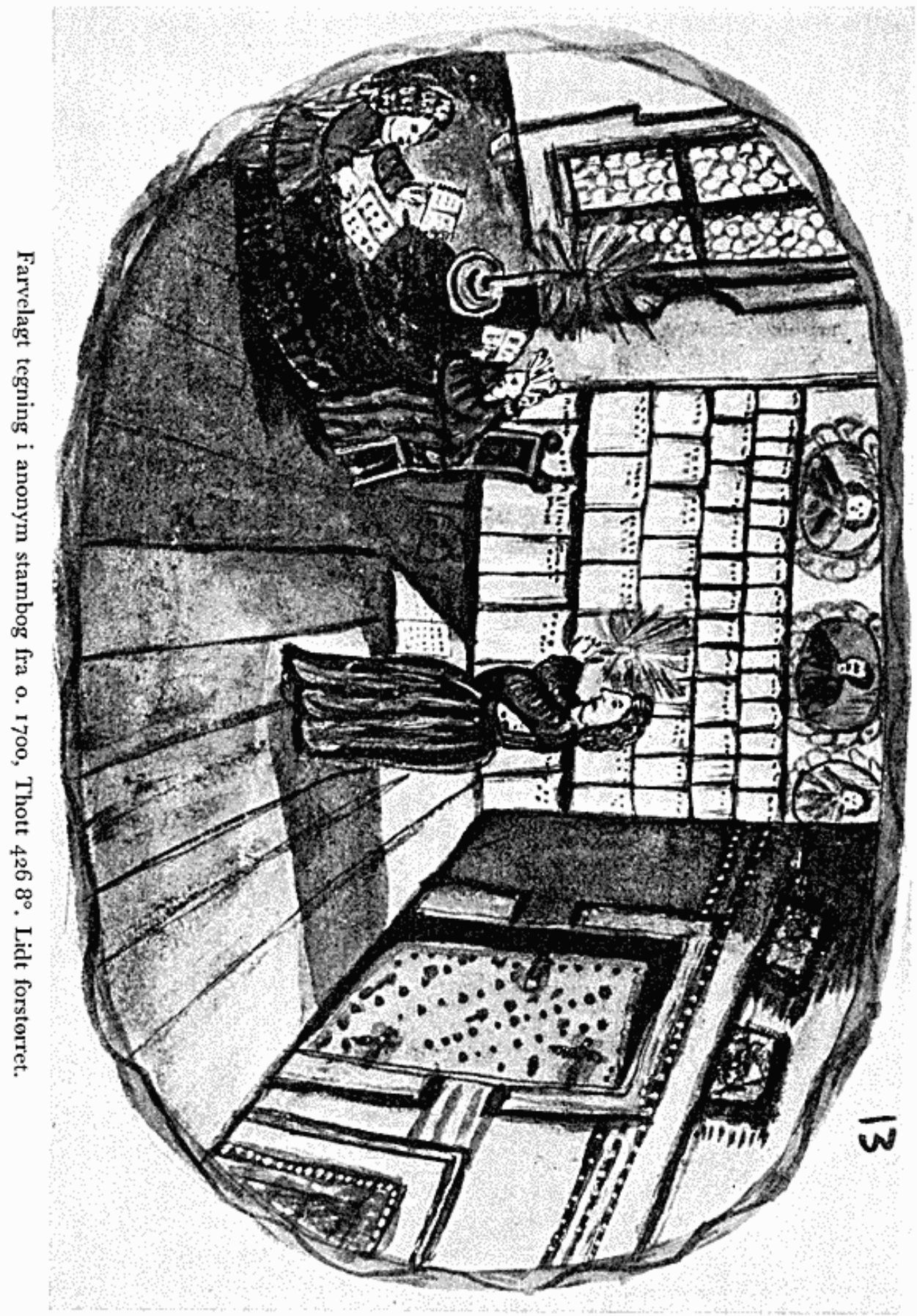


hørende en officers- og embedsmandsfamilie fra Mecklenburg med adskillige medlemmer i dansk tjeneste. Foruden ham forekommer nogle parsianere, der benytter deres hjemlige sprog og alfabet.

Enkelte stambogsejere har besøgt hertugdømmerne, navnlig det nye universitet i Kiel. I juni I68 I moder vi der David Lichtenhan, der senere blev livlæge i Merseburg. Albert Reinhold Liuders fra Hamburg blev immatrikuleret i Kiel 5.10.1712, og han synes at have opholdt sig der temmelig længe, idet de sidste indforsler er fra omkring 1724 , dog har han i mellemtiden også været i flere andre holstenske byer. To anonyme stambøger indeholder ligeledes indforsler fra Kiel, henholdsvis $\mathrm{I}_{7} \mathrm{O} 5 \mathrm{og}$ 1 713-14. Endelig er der en uidentificeret ejer af mange stambogsblade, der har opholdt sig i Altona og omegn i tiden ca. I 740.

Enkelte udenlandske stambogsejere er senere trådt i dansk tjeneste, og antagelig på denne måde er deres stambøger havnet i Danmark. Således trådte Nicolaus Johannes Wasserschlebes son Joachim 1738 i dansk tjeneste og gjorde sig bemærket som sekretær i Tyske Kancelli, diplomat i Paris og deputeret i Generaltoldkammer- og Kommercekollegiet. Da han trak sig tilbage og kom i pengeforlegenhed, købte staten $I_{7} 83$ hele hans kobberstiksamling, og senere kom hans ret omfattende historiske samlinger, derunder formentlig også hans faders stambog, til Kgl. Bibl. ${ }^{48}$ ) I $175^{2}$ blev Johan Friedrich Camerer fra Oettingen regimentsauditør i Haderslev, og efter sin afskedigelse 1768 udnæuntes han til ridefoged i Hvidding og Nørre Rangstrup herreder. Han udfoldede en ret omfattende, hovedsagelig statsøkonomisk, forfattervirksomhed, og det er gennem ham, O. H. Moller ${ }_{1} 76_{5}$ fik hans faders, lægen Georg Albert Camerarius' stambog.

Sprog og indhold. Indførslernes sprog ændrer sig kun langsomt i det I 7 .århundrede, men derefter noteres en betydelig tilbagegang for latinen og for de klassiske sprog i det hele taget, navnlig uden for professorers og lærdes kreds, mens levende sprog vinder frem, navnlig tysk, da mange stambogsejere er tyske eller har tyske forbindelser, og en stor del af dem studerer ved tyske universiteter. Fransk har altid været godt repræsenteret, og dets andel er stigende i begyndelsen af $\mathrm{i} 700$-tallet, som fransk indflydelse $\mathrm{i}$ det hele taget.

Der kan noteres en tendens til længere indførsler, som får en mere personlig karakter, der af og til tenderer mod det uanstændige. Uartige citater findes f.eks. i J. C. Kleffels stambog. På den anden side har også pietismen sat sine spor med dybtfølte religiøse citater og sentenser, bedst repræsenteret i B. G. Wessels og Jorgen Leths stambøger. 
Enkelte stambøger får ligefrem karakter som de senere poesibøger, med afskrifter af langere digte, der er forsynet med personlige tilføjelser. Et godt eksempel haves i Gustav Schrødters stambog, som endog er udstyret med et digtregister. Nic. Joh. Wasserschlebes stambog ( $170 \mathrm{O}-07)$ indeholder foruden sådanne digte tillige en række kompositioner. I andre stamboger forekommer lignende indforsler mere spredt. Enkelte digtere af lejlighedsvers benytter stambøger til deres arbejder, således Anders Beyerholm, der I $665_{5}$ i Jacob Caspergaards stambog brugte i i sider til mere eller mindre kunstfærdige hyldestdigte til forskellige medlemmer af familien og 1668 udbredte sig på næsten lige så mange sider hos Paul Nielsen Sass, idet han begræed dennes faders Niels Sass' og archidiakon Peter Dreiers bortgang.

Baroktidens foretrukne versemål: aleksandrinere, lånt fra klassisk fransk poesi, forekommer også i stambøgerne. De bedste eksempler findes $\mathrm{i}$ indledningerne, som undertiden kan være ret oplysende. Således skrev Peter Ayerschöttcl:

Wir schreiben in ein Buch, wass ewig soll bekleiben

Weil keinen nun ein Freund, kann in dass Hertze schreiben

So stifft es mir und ihm, hier ein Gedächtnus Mahl dass Handt und Hertz zu gleich, auss diesen Blettern Strahl

Im Fall auch Gunst und Kunst, mag so ein Blatt erfüllen So werd ich wo ich kann, bedancken solchen Willen ob schon ein Leib verdirbt, doch lebt hier ein die Handt von denen die uns hier, und dorten seint bekandt.

Hans kunstnerkollega Sigismund Ludwig Geyher benyttede lejligheden til at fremhæve malerkunstens betydning, men var dog også tilfreds med skrevne hilsener:

Die Mahlerey erlängt der Menschen kurtzes Leben, indem durch Ihre Kunst der Todten Bildnus bleibt,

Wir wollen Ihr den Ruhm in grossen Schalen geben, weil Sie Vergessenheit auss unssern Gräntzen treibt.

Durch Sie steht neben unss, der sonsten weit verreiset, Durch Sie erscheinen noch die alten auf der Weldt.

Solange man unss noch der Menschen Bildnus weiset, wird von der Mahlerey das grösste Lob gefällt.

Hier werthe Freundte wird kein Mahlrey aussgebetten mir fällt nur dieses ein, weil ich ein Mahler bin. 
Die Schreibefeder mag des Pinsels Stell' vertretten,

Sie setzt durch ihre Krafft auch offt was schönes hin.

Ihr werdet höchst geneigt auf diese Blätter schreiben auch Federn können das, wass sonst die Pinsel thun,

Ich werd ob solchen Dienst Euch ewig hold verbleiben,

Weil Eure Nahmen steets in diesen (!) Buche ruhn.

I begyndelsen af I 700-tallet blev grundtonen djærvere, samtidig med at venskabet dyrkedes mere inderligt. Ved siden af de dybt religiøse pietistisk prægede stambøger med lutter bibelcitater forekommer andre, hvor selv teologistudenter udtrykker glæde og forståelse for livets verdslige sider. Dette kan belyses ved en rakke eksempler fra Joh. Chp. Kleffels stambog, som spænder vidt $\mathrm{i}$ den henseende. En kæk teolog fra Schlesien, Daniel Theophil Cochlovius, skrev I5.7.1720 i Wittenberg, idet han tilføjede en duelscene som illustration:

Was mir gefällt, das ist: Ein Buch, und blankes Schwerdt

Ein paar Pistohlen, und ein wohlgesattelt Pferdt!

Hat mich jemand touchirt, so zeig ich ihm den Degen,

Ist ihm sein Leben lieb, so muss er mich erlegen.

En anden teolog, Joh. Sam. Voigt fra Franckenstein i Sachsen, prøvede 3 I.I.I723 i Leipzig at tilgodese både de himmelske og jordiske goder:

Dem Himmel opffre dein Gemüthe,

Und den galanten Leib der Welt,

Dess Morgens rühmst du seine Güte,

Des Nachts die, so dir gefällt.

So kanstu ohne Heuchel Schein,

Halb geistlich und halb weltlich seyn.

Han blev sekunderet af Joh. Gottlieb Uhlich fra Chemnitz, der 4.9.1 723 skrev den kortfattede, ret ofte benyttede version af samme tema, her i en tosproget udgave:

J'aime Dieu \& une belle Dame

L'un pour le corps, l'autre pour l'ame.

Jesum in Herzen, das Mägdgen in Arm.

Eines macht seelig, das andere macht warm. 
Ved et sikkert lystigt møde på „Neukrug 3 Stunden von Wittenberg“ den I 3.5.I 723 har flere studiekammerater indskrevet deres hilsener, særlig bramfrit den senere højt æstimerede hofpræst på Glücksborg Philip Ernst Lüders fra Flensborg, og lidt mere tilbageholdende Peter Steffens fra Ejdersted, senere advokat i Tønning, der digtede:
Als Adam und Eva sich heimlich versteckten da nahmen sie ein Feigen Blatt Womit Sie diejenige Schande bedeckten die Ihre Schuld entblösset hat:
Doch unsere Jungfern entblössen die Schande, Was macht es? Es wachsen keine Feigen im Lande.

Glaeden ved livet ledsages ofte af frygten for døden. I stærk modsætning til denne djærve og naive studenterpoesi står i samme stambog andre dybt alvorlige indforsler; f.eks. skriver Joh. Georg Mänling fra Kreuzburg i Wittenberg 27.2.1720:

\section{Was hilfft der Erden Schatz, was helffen ihre Titel Von aller Herligkeit bleibt nur der Sterbeküttel!}

Indførslen er illustreret med en ligskjorte, og måske havde skriveren allerede en forudanelse om sin snarlige bortgang. Af en tilføjelse fremgår det, at han er død i Jena 2.5.1 720, altså mindre end tre måneder efter at verset var skrevet.

Stambogsvers kunne også benyttes til at aflægge beretning, navnlig om studenterlivets genvordigheder. I Heinrich Daues stambog udbreder J. G. Unruh fra Lüneburg sig i en indforsel af I2.12.1740 i Jena over to sider med „Betrachtungen des heutigen Zustandes der Universität Jena", hvor han beklager sig over de nidkære moralens vogtere, som benytter enhver lejlighed til at slæbe de stakkels studenter til pedel eller prorektor, smide dem i studenterfængsel (carcer) eller i hvert fald idømme dem en klækkelig bøde.

Dansk er efterhånden ret godt reprasenteret, og med benyttelse af modersmålet kommer samtidig en friere tone. Enkelte forsøger at frigøre sig for de gængse stambogsvers og citater eller soger i hvert fald at omskrive dem i mere humoristisk retning. Der indflettes gerne en hentydning til ejeren. Den senere sogneprast i Jyllinge og Gundsømagle Ferdinand Treu skrev således under sine studier i Jena i august 1733 i G. J. Zwergius' stambog: 
Kiæmper Alle Folk forskrecker

Og som Voldsmænd Livet stecker,

Meer man elske maa een Dverg,

Dog kand Kiæmpe: Moed og Ere

I de rare Dverge vare

Dett beviiser Mons:r Zwerg.

Dertil føjede han sit valgsprog:

Snacke Dansk, I hulde Sønner

Hvilke Dannemark belønner.

Studenterhyldesten er dog intet at regne imod de panegyriske digte, som de kunstdyrkere, der opvartede Johanne Fosie, skrev i hendes stambog, idet de mobiliserede alle deres digteriske evner for at give udtryk for taknemmelighed og beundring. Et eksempel herpå leveres af E. S. Resch, der 1.2.1 747 skrev:

See smukke Jomfrue! see et meget ringe Stykke

Som ieg uvardig her for hende viiser frem

Udbeedende mig at det have maac den Lykke

Blandt andre deris og at nyde hendes Hiem

Det er kuns slet og ret, men hendes mange Dyder

Og store Artighed behageligen skal

Jo overskygge slet de Feil og store Lyder

Dem hun, som Mæster, seer at findes uden Tal.

Jeg siiger Master, thi hun dette meriterer

Blant store Mæstere hun billig regnes kand

Og vores Dannemark ey liidet sig flaterer

At det en Jomfrue har til Mæster i sit Land.

I begyndelsen af r 7oo-tallet besogtes ved siden af Jena ofte Halle, hvor interessen samlede sig om det berømte vajsenhus og dets stifter August Hermann Francke. Allerede 2.8.1694 skrev han i Glaucha i Monasse Monrads stambog, og den sidste hilsen er af 26.3.1727 kort før hans død, til Nicolaus Bernhard Ambders. I samme stambog havde dagen for sønnen Gotthilf August Francke skrevet, hvis navnetræk tillige findes hos Jens Henriksen Schou (20.3.1742) og Niels Randulf With (8.1. I 742). I Halle opholdt sig dengang også Adam Struensee, den senere superintendent i hertugdømmerne, fader til lægen med den hurtige og brat afsluttede kar- 


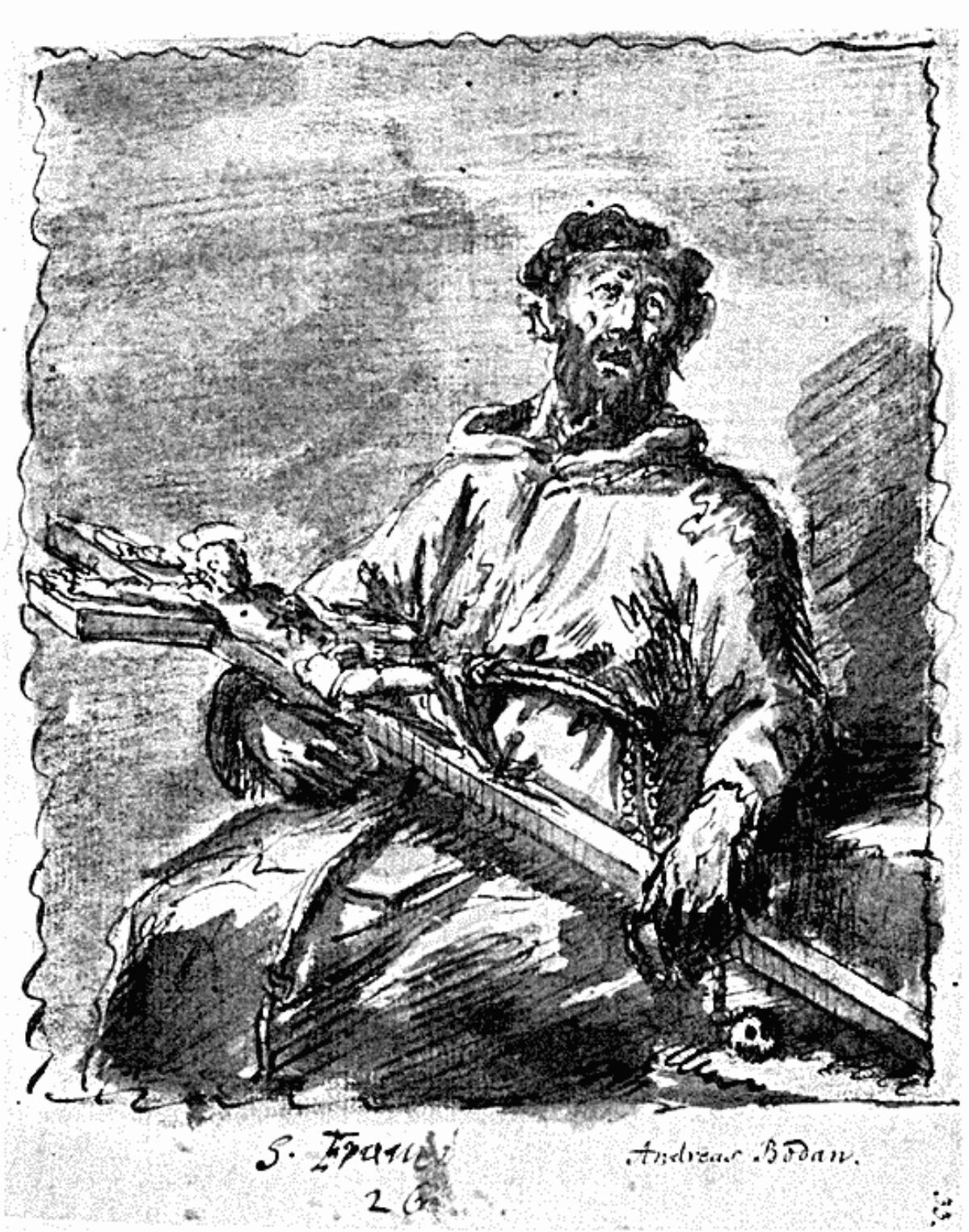

Den hellige Frans. Laveret tegning af Andreas Bodan $(1656-96)$ indsat i Sigismund Ludwig Geyhers stambog, Thott $12844^{\circ}$. Lidt formindsket.

riere $\mathrm{i}$ dansk tjeneste. Faderen havde fra $173^{2} \mathrm{i}$ et kvart århundrede sit virke som præst $\mathrm{og}$ skolemand i Halle, fra $\mathrm{I} 747$ havde han et teologisk professorat. Hans navn findes i flere stambøger, bl.a. hos Jens Henriksen Schou (23.3.1 742$)$.

Endelig kan nævnes fohann Andreas Manitius, medarbejder ved det jødi- 
ske institut i Halle, der 29.3. I 742 skrev en hilsen i sidstnævntes stambog - nogle måneder senere var han $\mathrm{i}$ København.

Tegninger og udstyr. Mens forholdsvis flere kunstnere anlægger en stambog, ofte rigt illustreret af venner og bekendte, bliver andre stambøger fattigere på sådant udstyr. Navnlig våbentegninger er efterhånden en sjælden foreteelse, findes undertiden på titelbladet, men er kvalitetsmæssigt betydelig ringere udført end de fine miniaturtegninger fra tiden ca. I570-1630. En undtagelse herfra udgør Terkel Klevenfeldts stambog, hvor den heraldisk interesserede ejer $\mathrm{I} 74^{2}$ har ladet tegne en rakke våbener $\mathrm{og}$ fået ejernes navnetræk $\mathrm{i}$ tilgift. I stedet for et manglende våben brugte man nu lejlighedsvis seglaftryk (Andr. Brückner).

Der forekommer de sædvanlige allegoriske motiver, og der tegnes også blomster og dyr, således findes i Heinrich Pohlmanns stambog en kluntet elefanttegning. Danske stambøger er iøjnefaldende fattige på de sædvanlige studenterlivsillustrationer, ejerne har måske ment at kunne spare denne udgift. De fleste tegninger af denne art findes i Joh. Chp. Kleffels stambog.

Mens man i r6oo-tallet endnu lagde vægt på bindet og papirets kvalitet, er de fleste stambøger fra begyndelsen af I 700 -tallet ret tarveligt udstyret og udviser en dårlig papirkvalitet, som ikke altid er blækfast. Mod periodens slutning spores en bedring, og dette gælder også illustrationernes mængde og kvalitet. Dette mærkes forst på titelbladet, som nu atter bliver udført med større omhu. Det er også en ret væsentlig detalje, ofte den eneste hjælp til at bestemme bogens ejer. Samtidig oges antallet af tegninger af studenterlivets særlige begivenheder, som navnlig blev foreviget ved de tyske universiteter.

Formatet er næsten udelukkende tværoktav, sommetider, navnlig i I 70o-tallet, betydelig længere og til dels bredere, således at det tangerer kvartformatet. Den egentlige oktav forekommer kun ved et par stambøger, som er fortsat i slægten, og ved Hans Gentzmers bog.

Afslutning. Den omhandlede periodes stambøger spænder vidt; det er en nedgangsperiode for de fornemme adelsstambøger, men opgangstid for djærve borgerlige venskabsbøger, blandet med pietismens sværmeriskinderlige med bønner og skriftsteder. Ejerkredsen udvides til lavere sociale lag med en religiøs skibskok på nederste trin. Studenterstambøgerne bliver nu i højere grad til venskabets templer, hvor dyrkelse af kammeratskabet ofte antager overdrevne former, en udvikling som fortsætter i næste periode og samtidig fører frem mod en ny kulmination. 
94. Zwergius, Gotthard Johan, fra Tønder, sognepræst i Moltrup, † I 751. I I 4 indforsler I 733-36 fra Jena, Halle, Glückstadt og Helsingør. - Prov.: Gave fra ejeren til O. H. Moller I74I (kat. nr. I02). - NKS $40 I, 8^{\circ}$.

95. Anonym. 44 indforsler 1653,1664 fra Nürnberg og Regensburg, med I portratstik. - Prov.: Temler s. 367 nr. 74 . - Tholl $440,8^{\circ}$.

96. Anonym, cand. jur., fra Anhalt. 75 indførsler $1659-66$, 1704 fra Dessau, Zerbst, Helmstedt, Braunschweig, Leipzig, Wittenberg, Liegnitz, Frankfurt a. d. O. o.a.st. - Prov.: Temler s. 366 nr. 49. - Thott $4^{21}, 8^{\circ}$.

97. Anonym, jurist (fra Nürnberg?). 4 indførsler $1660-63,1666$ fra Regensburg, Jena, Bremen og Wien i Joh. St. Deckers stb. - Thott $44^{I}, 8^{\circ}$.

98. Anonym, fra Oldenburg/Westfalen. $3^{8}$ indforsler ${ }_{1695}$ fra Halle. På forste blad M.E.G. I 713, derefter I7 sider med tegninger og skitser, desuden en tegning (s. I22). Ejeren muligvis identisk med Friedrich Joachim v. Münnich, sml. s. 249. - Prov.: Temler s. 366 nr. 54. - Thott $4^{26,} 8^{\circ}$.

99. Anonym, fra Celle. 94 indførsler $\mathrm{I}_{704-07}$ fra Jena, Eisenach, Berlin, Kiel o.a.st. - Thott $390,8^{\circ}$.

ıо. Anonym, fra Mecklenburg. I I indførsler I 709-16 fra Lübeck, Kiel og Koldenbüttel. - Thott $580,8^{\circ}$.

Ior. Anonym, fra Berlin(?). 8o indførsler I 722-30 fra Görlitz, Halle, Dresden, Leipzig, Töplitz, Berlin, Praha, Regensburg o.a.st. I våbentegning og ro andre ill. - Register foran i bogen. - Prov.: Temler s. 366 nr. 4o. - Thott $4{ }^{I} 3,8^{\circ}$.

102. Anonym, fra Hamburg(?). Stambogsblade ca. I $740-42$ fra Göttingen, Kassel, Hamburg, Altona, Elsfleth o.a.st. i Thott $5^{I I}, 2^{\circ}$.

\section{NOTER}

(1) Sml. hans rejseberetning, Memoirer og Breve XXIX, ${ }_{1919}$, s. 53 ff. - (2) Stambogen beskrevet af $\mathrm{H}$. D. Schepelern i: Kulturminder, ny rk. bd. V, $1965, \mathrm{~s} .76 \mathrm{ff}$. (3) J. F. Kinch, Ribe Bys Historie og Beskrivelse II, I884, s. 4 I I. Han forveksles ofte med bispen Hans Wandal (1624-75), således hos H. Friis-Petersen (Personalhist. Tidsskr. 14: III, 196r, s. 178) og i O. H. Mollers auktionskatalog. - (4) Th. O. Achelis, Matrikel der schleswigschen Studenten 1517-1864, 1966, (herefter citeret Achelis) nr. 2326. Sml. samme i: Heimatblätter für den Kreis Sonderburg 6, 1927, s. 72-78. - (5) Achelis nr. 2454. - (6) Achelis nr. 2716. - (7) Achelis nr. 2842. - (8) Achelis nr. 3963. (9) Achelis nr. 3087. - (10) Achelis nr. 3112a. - (11) Achelis nr. 3192. - (12) Achelis nr. $3^{8} 3$ I. - (13) Achelis nr. 3737. - (14) Achelis nr. $3^{8} 46$. - (15) Achelis nr. 3970. 
(16) Achelis nr. 5316. - (17) Achelis nr. 4224. - (18) Achelis nr. 46r9. - (19) Achelis nr. 3712. - (20) Achelis nr. 5045. - (21) Achelis nr. 5087. - (22) Achelis nr. 5277. (23) Achelis nr. 56r9. - (24) Achelis nr. 5760. - (25) Sml. Bjorn Kornerup, Ribe Katedralskoles Historic II, 1952, s. 35. - (26) Achelis nr. 3203. - (27) Achelis nr. 3778. (28) Sml. Vor Fortid III, I919, s. 37 Iff. - (29) Emil Madsen (Vor Fortid III, I9I9, s. $3^{67}$ ) går på grundlag af en seddel ud fra, at den tredie ejer har varet Elisabeth Henriksdatter Friis, en sonnedatter af Jesper Friis. Stambogen indeholder hendes egen indforsel (bl. I I 7: 4.8.1698 på Brudagergârd), skrevet på „Faster Lisabeths Begaring“.

(30) Alle i Weilbachs Kunstnerleksikon I-III, 1947-52, passim. - (31) Weilbach II, 1949, s. 395. - (32) Sml. ovf. note 1. - (33) Skibsjournal i Rigsarkivet, Vestindiske arkiver nr. 67o, bl. 20. - (34) Af andre pietistiske stamboger kan nævnes Lars Dalhoffs med indforsler fra 1733 , afskrift i Ledreb. $395,2^{\circ}$ (uddrag i: Kirkeh. Saml. 5 : IV, 1907o9, s. 358-365) og Jens Rennords fra 1734-38 (uddrag i: Kirkeh. Saml. 3: I, 1874-77, s. 370-387). - (35) Udforligt behandlet af Vello Helk i: Kirkch. Saml. 7: VI, 1968, s. 553-574. - (36) Otto Fr. Arends, Gejstligheden i Slesvig og Holsten II, I932, s. 246. (37) Arends II, s. 289. - (38) Áke Davidsson, Till vänskapens lov, Göteborg 197 I, s. 26f. - (39) Flere breve fra ham fra Tonning $1753-56$ i Ledreb. $431,2^{\circ}$. - (40) J. C. W. \& K. Hirsch, Danske og norske Officerer, I648-1814, III :2; sml. Personalhist. Tidsskr. I4: II, I96o, s. 92. - (41) I hans biografi (Dansk Biogr. Lex. (Bricka) XI, s. 260) navnes, at han blev gift 1754, men i stambogen indskriver hustruen Engel Margrethe Mengel sig allerede 21.6.1753. - (42) Fritz Graef i: Festschrift des Kunstgewerbemuseums der Stadt Flensburg, 1928, s. 281-299. - (43) Vello Helk i: Personalhist. Tidsskr. 16:IV, 1976, s. 75-83. - (44) Weilbach I, 1947, s. 52. - (45) Sml. F \& F XXI, I 974, s. 39 nr. 26: Isracl Haid. - (46) Chr. Gottl. Jöcher, Allgemeines Gelehrten-Lexicon II, Leipzig 1750, sp. I 725. - (47) Georg Seebass und Fr.-W. Freist, Die Pastoren der Braunschweigischen evangelisch-lutherischen Landeskirche I, [Wolfenbüttel] I969, s. 75. - (48) I Kgl. Bibl.s katalog anfores Sigm. Wasserschlebe som ejer. Ved at sammenholde stambogsindforsler og universitetsmatrikler kan dog kun Nic. Joh. W. komme på tale. Han blev immatrikuleret 24.7.170o i Halle (indforsler 1700-02) og 16.6.1 703 i Jena (indforsler $1703-04$ ). 


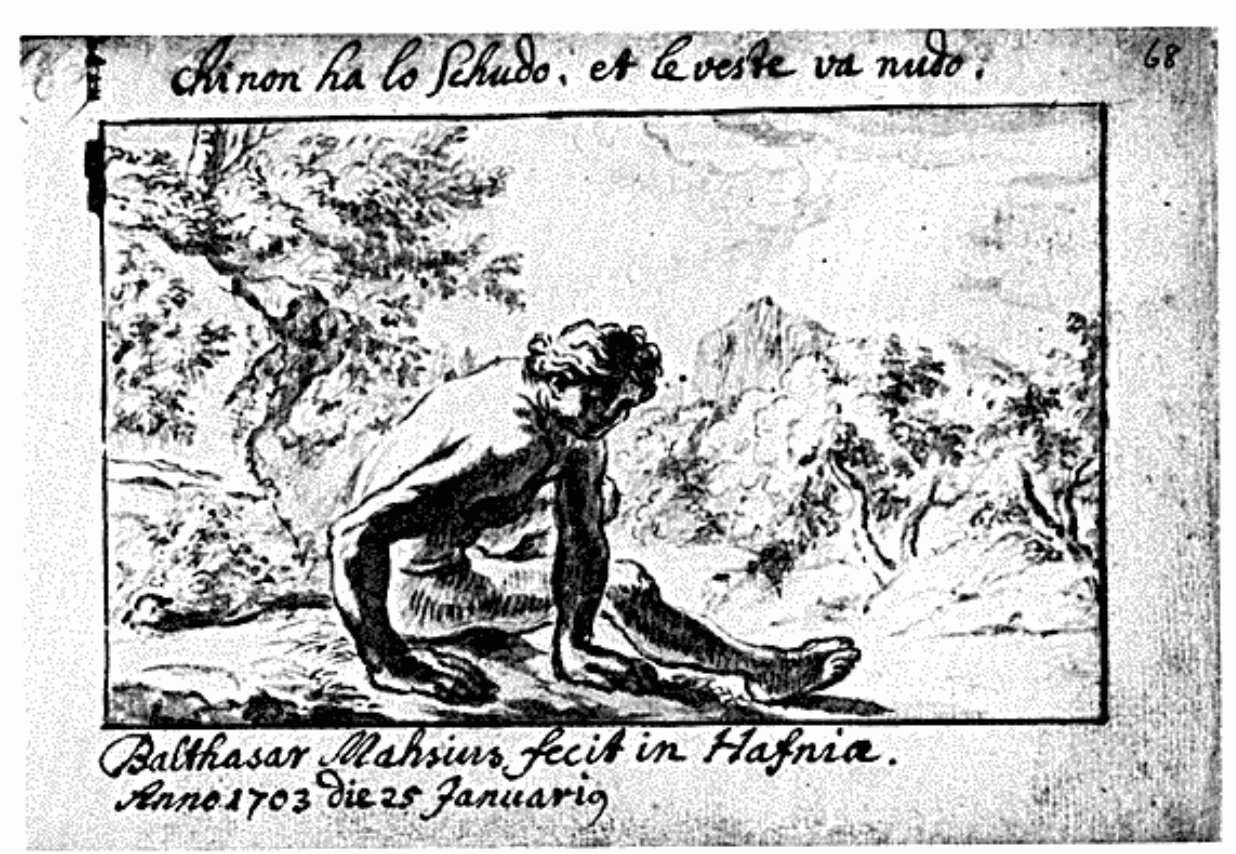

Laveret tegning af maleren Balthasar Masius, dateret Kobenhavn 25.1.1703, i den slesvigske maler N. C. Moritz' stambog. Overskriften: Den som ikke har penge og tøj må gå nogen. Thott $5698^{\circ}$. Lidt formindsket.

\section{Appendiks: Oversigt over ejere af stamboger og stambogsblade} fra tiden $165_{1-1750} i \mathrm{Kgl}$. Bibl.

Oversigten er udarbejdet efter samme retningslinier som oversigterne i F \& F XXI, I974, s. 36-44 og F \& F XXII, I975-76, s. 39-88. Anonyme stambogsejere anfores til sidst $\mathrm{i}$ alfabetet.

I. Ambders, Nicolaus Bernhard, fra Burkal, kollegiesekretær, justitsråd, $\dagger$ 1763. 121 indforsler $1726-37$ fra Greifswald, Leipzig, Halle, Jena, Helmstedt, Hamburg, København, Wien, Paris o.a.st. Indklæbet stambogsblade med indforsler af Philipp Melanchton d. y. I6oI, Hugo Grotius, Hamburg I633, og Hermann Conring, Helmstedt i64o (den sidste til Andreas Ambders, sml. F \& F XXII, s. 7of.), desuden et blad med indforsler fra Wittenberg 1678 og København 1686 (måske til Bernhard Lassæus, se denne). Med register - Thott $549,8^{\circ}$.

2. Axen, Johan Adolph, fra Slesvig, advokat, $\dagger$ efter 1 71 2. Stambogsblade ca. 1692-97 fra Kiel, Frankfurt a.d.O., Berlin, Leipzig, Wittenberg, Halle, Utrecht, London og Oxford i Thott $500,2^{\circ}$ og Thott $1059,2^{\circ}$. 
3. Ayerschöttel, Peter, fra Recife del Pernambuco (Brasilien), maler. 27 indførsler ${ }_{16} 6_{73-76}$ fra Altdorf, Nürnberg, Augsburg, München og Wien. 12 tegninger. - Prov.: Temler s. 367 nr. 71 . - Thott $437,8^{\circ}$.

4. Beimelits, antagelig Beimbl, Wolfgang Sebastian, fra Regensburg (imm. 28.6.1657 og 21.7.1659 i Altdorf). Stambogsblade ca. I659-70 fra Regensburg, Hamburg, Wedel, Krempe og Altdorf i Thott $500,2^{\circ}$ og Thott $1059,2^{\circ}$.

5. Bertram, Justus. Stambogsblade 1 $5^{1-52}$ fra København i Abrahams autografsaml., $4^{\circ}$ (nr. I24 og 306$)$.

6. Blumenthal, Johann Heinrich, fra Bröckel (Celle), lærer i Lüchow (Niedersachsen). 19 indforsler $1677-78$ fra Helmstedt. I tegning. Mange blade bortklippet, deraf $I_{7}$ med indforsler ${ }_{1} 677-78$ fra Lüneburg og Helmstedt i Thott $5_{5 I}, 2^{\circ}$. - Senere benyttet af Joh. Andr. Bortfeldt, archidiakon i Lüchow, til en fortegnelse over latinske citater (s. I-85), „Register der fürnehmsten Sachen“ (s. 87-1 20), „Index prosodiacus“ (s. I 2 I-I 32), „Collegium chiromanticum (s. 254-345, 348-368) og „Ars Medorum de somniis" (s. 369-400) med tilføjelser til de foregående. Prov.: Købt 1953 af Wandels antikvariat. - NKS $1055,8^{\circ}$.

7. Born(e)mann, Christian, fra Delitzsch (Sachsen), poeta laureatus, rektor i Mitau (Kurland), † I 7 I 4. 95 indforsler I66o-6r fra Jena, Wolfenbüttel, Hannover, Hildesheim, Hamburg, Braunschweig, Minden, Zerbst, Magdeburg o.a.st. Foran indfort mange lejlighedsdigte, valgsprog, stambogsvers o.l. På indersiden af forpermen en rakke navne, muligvis senere ejere, deriblandt Stephan Kenckel og Jac. Chp. Hersleb I $705 .-$ Add. $48 b, 8^{\circ}$.

8. Bornemann, Cosmus, fra Haderslev, jurist og borgmester i København, $\dagger$ 1692. $4^{8}$ indforsler $1656,1660-64$ fra Rostock, Kobenhavn, Franeker, Groningen og Amsterdam. 3 ill. samt Kobenhavns byvåben (stik). - $\mathcal{N} K S_{36 I}, 8^{\circ}$. Et enkelt blad (København ${ }_{1} 660$ ) i $\mathcal{N} K S_{128 g}{ }^{2}, 4^{\circ}$.

9. Bremermann, Peder Christoffersen, fra København, søn af islandsk købmand Christoffer B. 32 indforsler ${ }_{1} 65^{1}-53$ fra København og Wittenberg. Bag i bogen adskillige bønner („Formula introducendi puerperas“ og "Votum pro agrotii“). - Prov.: Danske Selskab. - $\mathcal{N} K S_{36}, 8^{\circ}$.

I0. Brückner, Andreas, maler. Io indforsler I680-87 fra Jauer, Propsthagen, Breslau, Danzig, Stettin o.a.st. 2 tegninger og I seglaftryk. Foran enkelte viseafskrifter. - Prov.: Temler s. 366 nr. $44 .-$ Thott ${ }_{4} 16,8^{\circ}$.

II. Buchwald, Frederik v., fra København, lage, $\dagger$ I752. I 21 indførsler 1733-35 fra Schleiz, Jena, Leipzig, Naumburg, Halle, Dresden, Lübeck, Rostock o.a.st. I tegning. Prov.: Temler s. 367 nr. 59. - Thott $550,8^{\circ}$. 
12. Böswillibald, Jacob Daniel, fra Lehmingen, præst i Flachslanden/ Ansbach, $\dagger_{I_{7}} 86.83$ indforsler ${ }_{1725-27}$ fra Wassertrüdingen, Lehmingen, Oettingen, Ansbach, Merckendorff, Jena o.a.st. Io våbentegninger og 2 andre ill. - Register foran. - Prov.: Temler s. $367 \mathrm{nr} .64$. - Thott $430,8^{\circ}$.

13. Camerarius (Camerer), Georg Albert, fra Oettingen, læge i Oe., $\dagger_{1} 7_{21}$. 83 indførsler 17 1 1-19 fra Tübingen, Ulm, Amsterdam, Leiden, Halle, Wittenberg, Jena, Dresden, Oettingen o.a.st. - Prov.: Gave fra ejerens søn, dansk krigsråd Joh. Fr. Camerer, til O. H. Moller ${ }_{17} 6_{5}$ (kat. nr. 81). - $\mathcal{N K S}_{364} b, 8^{\circ}$.

I4. Carstens, Nicolaus Gotthard, fra Lübeck. Stambogsfragment med 22 indførsler I697-1 700 fra Slesvig, Kiel, Lübeck, Hamburg, Helmstedt, Leipzig, Halle, Jena, Altdorf og Wittenberg. - Tholt $5^{8 r}, 8^{\circ}$.

I5. Caspergaard, Jacob, fra Vonsbak, sognepræst i Starup, $\dagger{ }_{1693}$. 67 indforsler 16 $52-9$ I fra Leiden, Franeker, Groningen, Utrecht, København, Leipzig, Halle, Wittenberg, Haderslev, Ribe o.a.st. (I tiden ca. 1671-75 udlånt til August Friedrich Jani fra Glückstadt til brug i Leipzig, Halle og Wittenberg). - Prov.: Gave fra Christopher Sass, Haderslev, til O. H. Moller 1745 (kat. nr. 18). Litt.: Th. O. Achelis i: Heimatblätter für den Kreis Sonderburg 6, I927, s. 72-8o. $-\mathcal{N} K S_{36} 6_{5} d, 8^{\circ}$.

16. Christophori, Michael, præst (fra Pommern?). Ca. 575 indforsler 1652-54 fra hertugdømmerne, Fyn, København, Jylland og Nordtyskland. - Thott $55^{2}, 8^{\circ}$.

Crudelius, Johann Jeremias, fra Jüterbog, se Siegfried, Johann, F \& F XXII, s. 83 f.

I 7. Dankwart, Johan, fra Husum, cand. theol., senere stud. jur. I28 indforsler I 744-54 fra Jena, Erfurt, Weimar, Quedlinburg, Hamburg og Koldenbüttel. Register foran. - Add. $48 c, 8^{\circ}$.

18. Daue, Heinrich, fra Lübeck, herredsfoged, Tyrstrup, † I $79^{\circ}$. 137 indførsler $1738-44,{ }_{75} 6$ fra Jena, Erfurt, Halle, Lübeck, Raschenberg, Odense, København o.a.st. 6 tegninger. Foran kort levnedsløb I $73^{8-45}$, fortsat af sønnen Severin Dauc. - Add. $43^{8}, 4^{\circ}$.

19. Dommer, J. C., fra Regensburg. 82 indforsler I 706-29 fra Regensburg, Dresden, Leipzig, London, Utrecht, Frankfurt a. M. I3 tegninger. Prov.: Temler s. 367 nr. 7 o. - Thott $436,8^{\circ}$.

20. Ernst, Wolfgang Philipp, fra Pappenheim (Franken), præst i Re-

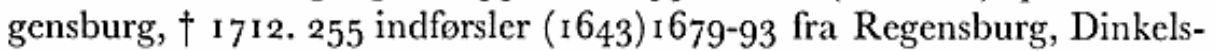
bühl, Pappenheim, Wittenberg, Halle, Dresden, Nürnberg, Altdorf, Augsburg, Nördlingen o.a.st. 2 våbentegninger og $\mathrm{I}$ anden ill. Prov.: Temler s. $366 \mathrm{nr} .46$. - Thott $4{ }^{8} 8,8^{\circ}$.

21. Fosie, Johanne, malerinde, $\dagger_{\text {1 } 764 .} 20$ indforsler $1747-58$ fra $\mathrm{K} ø-$ 
benhavn. 34 tegninger. - Prov.: Gave fra prof. N. L. Høyen. - $N K S$ $369 k, 8^{\circ}$.

22. Friis, Lisbeth, datter af Jesper F. og Elisabeth Ulfeldt, $\dagger_{1}$ I $_{1} 6$ (og hendes søster Sophie F.). Ca. Ioo indførsler I68I-1 702 fra Ørbæklunde, Holckenhavn, Brudagergård, Svendborg, Orebygård, Maribo, Hellerup, Nyborg, Søbysøgård, Brahetrolleborg, Lykkesholm, Hvedholm o.a.st. i El. Ulfeldts stb., Thott $560,8^{\circ}$, se F \& F XXII, s. 85.

23. Galli, Paulus, fra Diósgyör (St. Georgen), præst, senere exulant. I 38 indførsler $1654-56$, I674-75 fra Diósgyör, Sempron, Bratislawa, Wien, Wittenberg, Dresden, Halle, Leipzig, Cottbus, Wolfenbüttel, Helmstedt, Hamburg, Bauditz, Breslau, Görlitz o.a.st. - Thott $3^{81}, 8^{\circ}$.

24. Gentzmer, Hans, fhv. præst i Tandslet, $\dagger \mathrm{I} 68_{3}$. 126 indforsler 1669-82, hovedsagelig fra Fyn, men også fra Jylland (Fredericia), Langeland, Lolland, Falster, Sjælland og København, ofte med et tilføjet pengebeløb (almisse). Senere benyttet som optegnelsesbog for en lærer i Nykøbing F. ca. I 702-I9. - Prov.: Danske Selskab. - Litt. Vello Helk: Hr. Hans Pedersen Gentzmer i Tandslet. Om en alsisk præst og hans „stambog", i: Kirkehist. Saml. 7: VI, I968, s. 553-574. - NKS 374, $8^{\circ}$.

25. Gerstenbüttel, Joachim, fra Wismar. Stambogsblade ca. I667-68 fra Wismar, Goslar og Wittenberg i Thott $511,2^{\circ}$.

26. Geyher, Johann Christoph, fra Regensburg, cand. jur. I53 indforsler 1659-70, I 704-2 I fra Regensburg, Jena, Leipzig, Weimar, Braunschweig, Oldenburg, Wien o.a.st. 35 våbentegninger og 24 andre ill. Prov.: Temler s. $3^{67}$ nr. 77 . - Thott $443,8^{\circ}$.

27. Geyher, Sigismund Ludwig, fra Regensburg, maler. Ca. $3^{\circ}$ indforsler og $4^{\text {o }}$ tegninger, tildels indklabet, deriblandt nogle aldre, de fleste dog fra I673-83, I 704-19 fra Regensburg, Nürnberg, Würzburg, Wien, Praha o.a.st. - Prov.: Temler s. 365 nr. 7. - Thott 1284, $4^{\circ}$.

28. Giese, Joachim, fra Husum, hofpræst i Husum, $\dagger$ 1 712.56 indforsler $1670-75$ fra Kaltenkirchen, Lübeck, Hamburg, Helmstedt, Altdorf og Nürnberg. - Prov.: Gave fra Christian Giese til O. H. Moller

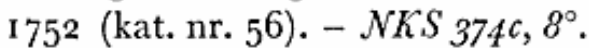

29. Hammerich, Maria Baack, $\dagger{ }_{7} 782.4$ indførsler ${ }_{1750-54}$. Benyttet J. G. W. Forstmann: „Evangelisches Blumen-Gärtlein ...“, LeipzigGörlitz 1747, gennemskudt med hvide blade (gave til ejerinden 14.5. I 748). Overvejende benyttet til familieoptegnelser, fortsat af Anna Elisabeth Hammerich, til 183 r. - Prov.: Fra retspræsident Kai Hammerichs bo 1938. - NKS $817,8^{\circ}$.

3o. Heurlin, Johann Daniel, fra Suhl. Stambogsblade ca. I654-55 fra Jena i Thott I2gI, $4^{\circ}$. 
31. Hoier, Nicolaus, fra Flensborg, diakon i F., † I 735. I99 indførsler I 7 1 2-16 fra Jena, Wittenberg, Halle og Naumburg. - Prov.: Gave fra Hoiers efterfolger Joh. Geerkens til O. H. Moller 1737 (kat. nr. 83). -

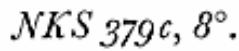

32. Holmer, Fr. August, fra Slesvig, hofråd på Gottorp, d. efter 1702 . Stambogsblad ${ }_{1} 674$ fra Jena i Thott $500,2^{\circ}$.

33. Holtzkampf, Johannes, fra Hamburg, mag., general Wrangels feltpræst. 46 indforsler ${ }_{16} 65^{2-54}$ fra Basel, Padova, Venezia, Nürnberg, Augsburg, Giessen, Rinteln, Hamburg, Uppsala, Danzig o.a.st. - Prov.: Danske Selskab. - $\mathcal{N} K S$ 378, $8^{\circ}$.

34. Hosmann, Sigismund, fra Helmstedt, præst i Celle, $\dagger$ г zor. I Io indforsler $1679-84$, 1693 fra Jena, Wittenberg, Lüneburg, Hamburg, Danzig, Königsberg, Riga, Mitau, Arensburg (Øsel), Stockholm, Uppsala, København o.a.st. Foran en række latinske sentenser. - Flere blade helt eller delvis fjernet, blokken beskadiget i højre kant. - Prov.: Gave fra Georg Friedrich Moller til O. H. Moller ${ }_{7} 785$ (kat. nr. 59). - NKS $378 d, 8^{\circ}$.

35. Febsen, Stephan, fra Rendsborg, prest i Flensborg, $\uparrow \mathbf{1} 720.45$ indforsler $1670-80$, I 684 fra Lcipzig, Königsberg, Frankfurt a. d. O., Küstrin, Berlin, Jena, Hamburg, Utrecht, Leiden, Oxford o.a.st., med I tegning, i Stephan Klotz' og Joh. Jebsens stb. $\mathcal{N} K S{ }_{36} 6,8^{\circ}$, se F \& F XXII, s. 77 f. 36. Jessen, Johannes Richard v., fra Preetz. 4 indførsler 1733 fra Jena i Joh. v. Jessens stb., Thott 1941 , $4^{\circ}$, se F \& F XXII, s. 77.

37. Jessen, Paul, fra Bredsted, diakon i Bordelum, † 1694 . 109 indforsler I656-6o, I663 fra Flensborg, Bredsted, Lüneburg, Leipzig, Wittenberg, Jena, Halle, Braunschweig o.a.st. I tegning (af Samuel Naaman, Bredsted, 28.2.1657). - Prov.: O. H. Moller nr. 50. - NKS 379e, $8^{\circ}$.

38. Kahlen, Antonius, fra Lübeck. $3^{8}$ indforsler 1691-94 fra Jena og Leipzig. 2 tegninger. - Thott $379,8^{\circ}$.

39. Kahrstädt, Georg Christian, superintendent i Dettum v. Wolfen-

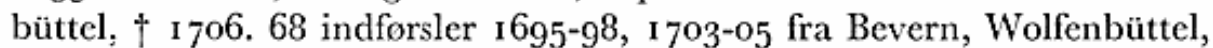
Helmstedt, Hofminden, Bremen, København, Stockholm, Uppsala o.a.st. 7 tegninger og I miniatureportræt. - Register bag i bogen. - NKS $4 I I, 8^{\circ}$.

40. Kall, Abraham, fra Flensborg, præst i F., $\dagger$ i 756.66 indførsler I 702-09 fra Halle og Glaucha. I tegning. - Prov.: Gave fra Joh. Chr. Kall til O. H. Moller I 740 (kat. nr. 77). $-\mathcal{N} K S$ 379 $k, 8^{\circ}$.

4I. Kall, Johan Christian, fra Flensborg, orientalist, $\dagger_{1775 .} 5 \mathrm{I}$ indforsler $173^{2-38}$ fra Hamburg, Jena, Halle, Naumburg, Weimar og København. Register bag i bogen. - Prov.: Gave fra ejeren til O. H. Moller ${ }^{1} 73^{8}$ (kat. nr. IOI). - NKS $379 l, 8^{\circ}$. 
42. Kleffel, Johann Christoph, fra Tangermünde, rektor i Tonning, $\dagger$ 1753. I70 indførsler $1720-27$, I 739, I 741 fra Wittenberg, Braunschweig, Helmstedt, Leipzig, Hamburg, Lübeck, Kiel, Rendsborg, Slesvig, Tønning o.a.st. 24 tegninger samt 2 stik fra Helmstedt. - NKS ${ }_{177} c$, $8^{\circ}$. Hans anden stambog fra samme tidsrum i UB Göteborg, se Åke Davidsson, Till vänskapens lov, Göteborg 1971, s. $26 \mathrm{f}$.

43. Klevenfeldt, Terkel, genealog, $\dagger_{\mathrm{I}} 777$. $\mathrm{I} 7$ indforsler $\mathrm{I} 742$ fra $\mathrm{K} ø$ benhavn. 13 våbentegninger. - $\mathcal{N} K S_{380,8^{\circ}}$.

44. Kluge, Johann Daniel, fra Weissenfels (Sachsen), superintendent i Zerbst, $\dagger_{\text {I }} 768$. 3 I indforsler $1722-26$ fra Weissenfels, Leipzig og Wittenberg. - Prov.: Temler s. 366 nr. $5^{\circ}$. - Thott $4^{22}, 8^{\circ}$.

45. Krag, Jytte, g. m. Axel Sehested (d. I 7 Io), $†$ for I 7 I2. Ca. 20 indførsler 1683-99 fra Viborg, Starupgård, Timgård og Nøragergård i Dorte Gjøes stambog, Thott ${ }_{155}, 8^{\circ}$, se F \& F XXI, s. 39. Litt.: Vor Fortid III, 1919, s. 371.

46. Krügelstein, Peter Christoph v., fra Braunschweig. 8I indforsler 1693-96 fra Braunschweig, Helmstedt, Wolfenbüttel, Naumburg, Leipzig, Halle, Leiden og London. 3 tegninger. - Kall 66I, $8^{\circ}$.

47. Lass, Johan, fra Husum, borgmester, $\dagger_{1} 7_{7} 84 \cdot 3^{8}$ indforsler $\mathrm{I} 74^{\mathrm{I}-4}{ }^{2}$ fra Halle og Jena. Prov.: Gave fra ejeren til O. H. Moller i 744 (kat. nr. I ro). - NKS $382 h, 8^{\circ}$.

48. Lassaus, Bernhard, fra Tønder, stud. theol., $\dagger$ efter 1706.36 indførsler I673-85 fra Tønder, Slesvig, Kiel, Rostock, Leipzig, Wittenberg, Magdeburg, Helmstedt, Hamburg og Lübeck samt 2 senere indforsler, den ene I 72 I i Burkal (antagelig til N. B. Ambders). I våbentegning. Prov.: Gave I 719 fra fru Nissen til N. B. Ambders. - Thott $558,8^{\circ}$. Dertil slutter sig til Thott $55^{8 a}, 8^{\circ}$, som indeholder dels udrevne blade fra den foregående stambog, med 19 indforsler fra samme tidsrum, dels løse blade fra andre stambøger, således 2 blade $1602-03$ fra Johs. Lassæus' stb. (F \& F XXI, s. 4o), 6 blade 1632-33 fra Lübeck og Wittenberg og 2 blade fra N. B. Ambders stambog, Paris 1737. Se tillige Ambders, Nicolaus Bernhard.

49. Leth, Jørgen, sognepræst i Dalum, $\dagger_{17} 787.5^{1}$ indførsler ${ }_{1736-38}$ fra København, Ribe, Jena, Halle, Hamburg o.a.st. Benyttet „Güldenes Schatz-Kästlein der Kinder Gottes", Halle 1734, med blanke venstresider. - Prov.: Gave 1968 fra overbibliotekar Torben Glahn. - $\mathcal{N} K S$ $124^{2}, 8^{\circ}$.

50. Leyser, Polycarp. Stambogsblade ca. 169o-93 fra Wittenberg, Langensalza, Leipzig, Halle o.a.st. i Thott $129 I, 4^{\circ}$.

51. Lichtenhan, David, fra Schneeberg, livlæge i Merseburg, $†$ I 733 . 
Stambogsblade ca. 1679-82 fra Jena, Leipzig, Kiel, Hamburg, Utrecht og Leiden i Thott I29I, $4^{\circ}$.

52. Lüders, Albert Reinhold, fra Hamburg. Stambogsblade ca. I 7 i $2-$ 44 fra Dänischenhagen, Kiel, Preetz, Hamburg, Altona o.a.st. (med tilfojelser om senere skabne) i Thott $5_{1 I} 2^{\circ}$.

53. Lüders, Christian August, fra Freienwillen/Grundhof, ejer af F., $\dagger$ I 739. 79 indforsler 17 16-2 I fra Wittenberg, Halle, Leipzig, Jena og Slesvig. 2 våbentegninger og 2 andre ill. - Tholl $5_{5} 6_{4}, 8^{\circ}$.

54. Malmogitu, Peter, fra Flensborg, sognepræst i Kropp, $\dagger$ I 73I. 64

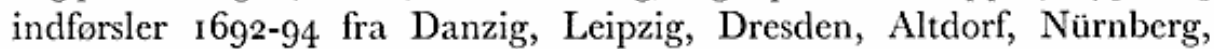
Coburg, Schleusingen, Schmalkalden, Eisenach, Erfurt, Weimar, Jena, Schulpforta, Wittenberg, Magdeburg o.a.st. - I ill. - Prov.: Gave fra Broder Ingversen, archidiakon i Husum, til O. H. Moller I759 (kat. nr. 67). - NKS $_{3} 86 n, 8^{\circ}$.

55. Mejer, August Franz, fra Lübeck, jurist, kannik i L., $\dagger$ I 703 . 82 indførsler ${ }_{1} 676-79$ fra Lübeck, Rostock, Jena o.a.st. 2 ill. - Thott $3^{8} 4,8^{\circ}$.

56. Mencelius, Johann Wilhelm, søn af lage Joachim M., fra Strelitz. 48 indforsler $163^{-8} 4_{4}$ fra Regensburg, Dessau, Zerbst, Jena, Leipzig o.a.st. - Prov.: Temler s. 366 nr. 51. - Thott $423,8^{\circ}$.

57. Mengel, Christian Gottlob, fra Schweidnitz/Schlesien, boghandler i Kobenhavn, $\dagger_{1769 .}{ }^{1}$ indførsler ${ }_{1739-62}$ fra Dresden, Lcipzig og Kobenhavn. 3 ill. - Prov.: Temler s. 368 nr. 84 . - Thott 566, $8^{\circ}$.

58. Moltke, Johan, boghandler i Kobenhavn, $\uparrow$ 1664. 99 indforsler 1653-6r fra Kobenhavn, Stralsund, Greifswald, Rostock, Wittenberg, Leipzig, Tübingen, Heidelberg, Nürnberg, Strassburg, London, Paris, Amsterdam, Hamburg o.a.st. 2 våbentegninger og 3 andre ill. - Thott $568,8^{\circ}$.

59. Monrad, Manasse, fra Ketting, sognepræst i Tommerup, $\dagger^{1} 7_{4} \mathrm{I}$. 26 indforsler $1693-95$ fra Wittenberg, Leipzig, Jena, Halle, Eisleben, Hamburg o.a.st. - Prov.: Gave fra sønnen Johan Ephraim M. til O. H. Moller 1744 (kat. nr. 7 o). $-\mathcal{N K S}_{3} 86 r, 8^{\circ}$.

6o. Moritz, Nicolai Christian, fra Slesvig, maler, † I 732. I 3 indforsler $1702-32$ fra Danzig, Kobenhavn, Christiania, London og Slesvig samt ca. 7 o skitser, tegninger o.a. ill. - Prov.: Temler s. 366 nr. 35. Thott $569,8^{\circ}$.

Münnich, Friedrich Joachim v., se nedenfor nr. 98 .

61. Paritius, brodrene, fra Schlesien, malere. I33 indforsler 1683I713 fra Brieg, Dessau, Merseburg, Berlin, Leipzig, Breslau, Zerbst, Halle, Bernburg, Köthen, Mühlberg o.a.st. I tegning. - På bindet mono- 
gram „C.I.P.“ med årstal „1674“, sandsynligvis Christian Jacob Paritius, hofmaler hos hertug Leopold af Anhalt I694-I 708. (Muligvis ejer af Aegidius Guntsch's stb., se F \& F XXII, s. 75 nr. 49 og Israel Haids stb., F \& F XXI, s. 39 nr. 26). - Prov.: Temler s. 365 nr. I6. - Thott $1290,4^{\circ}$.

62. Pasch, Georg, fra Danzig, professor, sidst i teologi, i Kiel, † I 707. I64 indforsler I684-89 fra Wittenberg, Jena, Weimar, Breslau, Altdorf, Augsburg, Giessen, Strassburg, Franeker, Leiden, Groningen, Utrecht, London, Bruxelles, Kiel o.a.st. - $\mathcal{N} K S_{449}, 8^{\circ}$.

63. Paulli, Christian, søn af kgl. livlæge Simon P., $\dagger$ 1679. 33 indforsler $1663-71$ fra København, Sorø og Helmstedt. Prov.: Gave I835 fra Thorvald Hornbech til UB. - Add. $74,8^{\circ}$.

64. Pfannenschmid, August Ludwig, fra Clausthal. Stambogsblade ca. I 731-34 fra Clausthal, Osterode, Helmstedt og Jena i Thott $5 I I, 2^{\circ}$.

65. Pohlmann, Heinrich, fra Hamburg, jurist, kgl. kancelli- og justitsråd i Glücksborg, † I 720. I 2 indforsler $1653-54$ fra Hamburg, Leipzig, Jena, Wittenberg og Weimar. I tegning (elefant). Prov.: Temler s. 368 nr. 83. - Thott $449,8^{\circ}$.

66. Rüdiger, Georg, fra Scheibenberg/Meissen. $19^{8}$ indførsler $1658-83$ fra Regensburg, Nürnberg, Altdorf, Weimar, Jena, Augsburg, Strassburg, Colmar, Eger o.a.st. 19 våbentegninger og 5 andre ill. - Prov.: Temler s. 367 nr. 69. - Thott $435,8^{\circ}$.

67. Sack, Jens Ebbesen, sognepræst i Tim-Madum o. 1652-6o. Stambogsblad $165^{2}$ fra Franeker i $\mathcal{N} K S_{1977 b} 4^{\circ}$ (gengivet i Bjorn Kornerup: Ribe Katedralskoles Historie II, I952, s. 35).

68. Sass, Nicolaus Gottfred, fra Haderslev, præst i H., $\dagger$ I 755.42 indforsler 1697-1 700 fra Leipzig, Jena, Wittenberg, Haderslev, Bjert og København. Prov.: Exlibris Frederik Heymann på indersiden af forpermen. Købt på auktion i $949 .-\mathcal{N} K S g_{1} 8,8^{\circ}$.

69. Sass, Paul Nielsen, fra Assens, archidiakon i Haderslev, $\dagger$ I 700. 78 indførsler $1666-98$ fra Wittenberg, Torgau, Dresden, Hamburg, Haderslev, Assens, Odense, København o.a.st. - Købt af Anker Kyster 1908. - $\mathcal{N} K S_{524}, 8^{\circ}$.

70. Scharffenberg, Hieronymus Caspar, fra Frankenhausen/Thüringen. 38 indførsler I66 I-66 fra Nürnberg, Jena, Altdorf, Regensburg og Altenburg. I tegning. - Prov.: Temler s. 367 nr. 72 . - Tholl $438,8^{\circ}$.

71. Schmollius, Wolfgang Matthacus, fra Regensburg, stud. theol. og informator hos friherrefamilien Geyer. 283 indførsler $1658-66$ fra Regensburg, Altdorf, Ulm, Augsburg, Coburg, Jena, Gotha o.a.st. - 12 våbentegninger og 9 andre ill. - Prov.: Temler s. 367 nr. 65. - Thott $431,8^{\circ}$. 
72. Schou, Jens Henriksen, sognepræst i Kippinge, † I 754. 25 indforsler ${ }_{1} 742$ fra Halle, Kloster Bergen, Magdeburg og Lübeck. - Add. $76,8^{\circ}$.

73. Schram, Andreas, fra Thorn, stud. jur. Stambogsblade ca. I 713-19 fra Thorn, Leipzig, Danzig, Elbing og Königsberg i Thott $5_{51} 2^{\circ}$.

74. Schreiber, Friedrich Gabriel, fra Glückstadt. 40 indførsler I 705-I I fra Glückstadt, Jena, Halle, Wittenberg og Berlin. - Prov.: Temler s. 367 nr. 56 . - Thott $4^{28}, 8^{\circ}$.

75. Schrödter, Gustav, fra Güstrow, legationspræst, sen. sognepræst i Süderau og Glückstadt, $\dagger^{\prime} \mathbf{7} 722.42$ indførsler (digte) I689-92 fra Schwerin og Wittenberg. Digtregister bag i bogen. - Prov.: Temler s. 366 nr. 53. Thott $425,8^{\circ}$.

76. Seckmann, Balthasar, deputeret i Generalkommissariatet, $\dagger$ I 722. I4 indforsler I669-7I fra Strassburg, Worms, Frankfurt a. M., Leiden og København. Foran overvejende franske og italienske digte. - Thott $574,8^{\circ}$.

77. Sellius, Burchard Adam, fra Tønder, historiker, $\dagger_{\mathrm{I}} 745.57$ indførsler I 727-30 fra Jena, Erfurt, Leipzig, Halle, Wittenberg, Braunschweig, Breitenburg, Kiel, Slesvig, Flensborg og Tønder. Register bag i bogen. - Litt.: V. Helk: Om Burchard Adam Sellius, i: Kirkehist. Saml. 1973, s. 87-91. - Prov.: O. H. Moller nr. 93. - NKS 396f, $8^{\circ}$.

78. Settelle, Ferdinand Emanuel, fra Regensburg. 29 indførsler I 7o9I 2 fra Jena, med to stik fra Jena. - Prov.: Temler s. $366 \mathrm{nr}$. 36 . - Thott $409,8^{\circ}$.

79. Steinhammer, Johannes, fra Bregling/Nybøl, rektor i Frederiksstad,

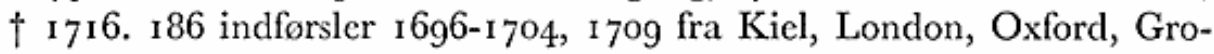
ningen, Haarlem, Amsterdam, Rotterdam, Slesvig, Berlin, Leipzig, Halle, Hamburg o.a.st. - Prov.: Gave fra Abraham Kall, præst i Flens-

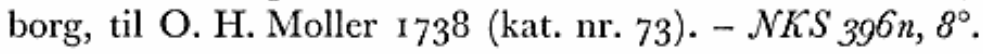

8o. Stockmann, Johann Christian, fra Holdenstedt/Sachsen, sogneprast i Drelsdorf, $\dagger_{\mathbf{~} \mathbf{7 5 3} .92}$ indførsler $\mathbf{1} 7 \mathbf{1 6 - 4 0}$, I 748 fra Halle, Jena, Leipzig, Sangershausen, Eisleben, Preetz, Bornhøved, Kappel, Helsingør, København, Flensborg, Drelsdorf o.a.st. I tegning (kiromantisk). - Register foran i bogen. - Prov.: Gave fra Joh. Gottfr. Moller i Nortorf til O. H.

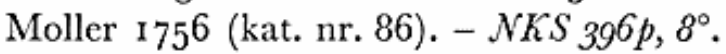

81. Stur, Bartholomaus. 5 indførsler $165^{1-52}$ fra Riga og Wilna i Sig. Ben. Mosers stb., Thott $429,8^{\circ}$, se F \& F XXII, s. 80.

82. Sörgels, Johann Adam, mag. Stambogsblade ca. I662 fra Jena i Thott $500,2^{\circ}$.

83. Wandal, Jens, fra Ribe, $\dagger$ 1659. 85 indforsler $1657-59$ fra Rostock, $5^{\bullet}$ 
Stralsund, Greifswald, Leipzig, Wittenberg, Wolfenbüttel, Giessen, Köln, Francker, Haag o.a.st. - Prov.: O. H. Moller nr. 52. - NKS 4 or $c, 8^{\circ}$. 84. Wasserschlebe, Nicolaus Johannes, fra Salzwedel, borgmester i S. I 12 indførsler I 70I-07 fra Halle, Jena, Eisenach, Dannenberg, Lübeck, Berlin, Frankfurt a. d. O. o.a.st. 2 tegninger og mange kompositioner. Begyndelsen (indtil s. 104) mangler. $-\mathcal{N} K S_{177}, 8^{\circ}$.

85. Vedel, Bagge Laugesen, degn i Ejsing, $\dagger$ I 775.6 indforsler ${ }_{1} 723-24$ fra Wittenberg i Lauge Andersen Vedels stb., Add. ${ }_{110}, 8^{\circ}$, se F \& F XXII, s. 86.

86. Werner, August, fra Waldenburg/Sachsen, dr. med. I 88 indforsler I671-79, I692 fra Naumburg, Jena, Erfurt, Nürnberg, Venezia, Padova, Altdorf, Augsburg, Halle, Helmstedt, Hildesheim, Braunschweig o.a.st. I tegning (Naumburg). - Kall 662, $8^{\circ}$.

87. Wessel, Bastian Gerhard, skibskok. I39 indforsler I740-53 fra Lauchstädt, Fredensborg, Kobenhavn, Haderslev, Altona, Wernigerode, Halle, Köthen, Slesvig, Nyborg, Roskilde, Kap det Gode Håb, Trankebar o.a.st. Benyttet: Herrn W. Ludwigs Grafen Henckels Schatzkästlein, Gratz I 735, med blanke venstresider. - Kall 680, $8^{\circ}$.

88. Wilmsen, Conrad, fra Slesvig. $7^{6}$ indforsler $1704^{-06}$ fra Kiel, Slesvig, Rostock, Wittenberg, Halle, Jena, Leipzig, Erfurt, Helmstedt, Lüneburg, Altona o.a.st. I tegning. - Prov.: O. H. Moller nr. 78. $\mathcal{N} K S_{401} i, 8^{\circ}$.

89. With, Niels Randulf, fra Slagelse, sognepræst i Tårnby, $\dagger_{1788 .}$ I9I indførsler $174^{2-4^{8}}$ fra Kobenhavn, Slagelse, Kolding, Hamburg, Leipzig, Halle, Erfurt, Jena, Wittenberg, Weimar, Göttingen, Broager, Augustenborg o.a.st. I stik (Göttingen). $-\mathcal{N} K S$ for $l, 8^{\circ}$.

9o. Woldenberg, Johann, fra Itzehoc. 64 indførsler $1652-57$ fra Rostock, Königsberg, Itzehoe, Franeker, Haag, Bruxelles, Amsterdam, Köln, Sedan, London, Paris o.a.st. I tegning. Navnefortegnelse foran i bogen. - Prov.: Temler s. 366 nr. 55. - Thott $427,8^{\circ}$.

91. Vollmar, Carl Gottfried, fra Zerbst, cand. jur., stadssekretar i Z. I9 indforsler 1682-86, I706-07 fra Wittenberg, Zerbst og Strassburg. Prov.: Temler s. 366 nr. $3^{8}$. - Thott $4^{I I}, 8^{\circ}$.

92. Worm, Willum, justitiarius, $\dagger_{17} 704.35$ indforsler ${ }_{1} 65_{2}-63$ fra København, London, Louvain, Leiden, Strassburg, Tübingen, Augsburg, Padova, Rom og Mantova. - Litt.: H. D. Schepelern i: Kulturminder, ny rk. bd. V, ig $66_{5}$, s. 76 ff. - Rostg. $3^{2}, 8^{\circ}$ (afskrift $N K S{ }_{21} 64,4^{\circ}$ ).

93. Worm, Willum, hofretsassessor, digter, $\dagger_{\mathrm{I}} 737$. I9 indforsler $172 \mathrm{I}-$ 24, 1729 fra Halle, Leipzig, Rotterdam, Paris og Kobenhavn. - Thott $577,8^{\circ}$. 
94. Zwergius, Gotthard Johan, fra Tønder, sognepræst i Moltrup, † I 751. I I 4 indforsler I 733-36 fra Jena, Halle, Glückstadt og Helsingør. - Prov.: Gave fra ejeren til O. H. Moller I74I (kat. nr. I02). - NKS $40 I, 8^{\circ}$.

95. Anonym. 44 indforsler 1653,1664 fra Nürnberg og Regensburg, med I portratstik. - Prov.: Temler s. 367 nr. 74 . - Tholl $440,8^{\circ}$.

96. Anonym, cand. jur., fra Anhalt. 75 indførsler $1659-66$, 1704 fra Dessau, Zerbst, Helmstedt, Braunschweig, Leipzig, Wittenberg, Liegnitz, Frankfurt a. d. O. o.a.st. - Prov.: Temler s. 366 nr. 49. - Thott $4^{21}, 8^{\circ}$.

97. Anonym, jurist (fra Nürnberg?). 4 indførsler $1660-63,1666$ fra Regensburg, Jena, Bremen og Wien i Joh. St. Deckers stb. - Thott $44^{I}, 8^{\circ}$.

98. Anonym, fra Oldenburg/Westfalen. $3^{8}$ indforsler ${ }_{1695}$ fra Halle. På forste blad M.E.G. I 713, derefter I7 sider med tegninger og skitser, desuden en tegning (s. I22). Ejeren muligvis identisk med Friedrich Joachim v. Münnich, sml. s. 249. - Prov.: Temler s. 366 nr. 54. - Thott $4^{26,} 8^{\circ}$.

99. Anonym, fra Celle. 94 indførsler $\mathrm{I}_{704-07}$ fra Jena, Eisenach, Berlin, Kiel o.a.st. - Thott $390,8^{\circ}$.

ıо. Anonym, fra Mecklenburg. I I indførsler I 709-16 fra Lübeck, Kiel og Koldenbüttel. - Thott $580,8^{\circ}$.

Ior. Anonym, fra Berlin(?). 8o indførsler I 722-30 fra Görlitz, Halle, Dresden, Leipzig, Töplitz, Berlin, Praha, Regensburg o.a.st. I våbentegning og ro andre ill. - Register foran i bogen. - Prov.: Temler s. 366 nr. 4o. - Thott $4{ }^{I} 3,8^{\circ}$.

102. Anonym, fra Hamburg(?). Stambogsblade ca. I $740-42$ fra Göttingen, Kassel, Hamburg, Altona, Elsfleth o.a.st. i Thott $5^{I I}, 2^{\circ}$.

\section{NOTER}

(1) Sml. hans rejseberetning, Memoirer og Breve XXIX, ${ }_{1919}$, s. 53 ff. - (2) Stambogen beskrevet af $\mathrm{H}$. D. Schepelern i: Kulturminder, ny rk. bd. V, $1965, \mathrm{~s} .76 \mathrm{ff}$. (3) J. F. Kinch, Ribe Bys Historie og Beskrivelse II, I884, s. 4 I I. Han forveksles ofte med bispen Hans Wandal (1624-75), således hos H. Friis-Petersen (Personalhist. Tidsskr. 14: III, 196r, s. 178) og i O. H. Mollers auktionskatalog. - (4) Th. O. Achelis, Matrikel der schleswigschen Studenten 1517-1864, 1966, (herefter citeret Achelis) nr. 2326. Sml. samme i: Heimatblätter für den Kreis Sonderburg 6, 1927, s. 72-78. - (5) Achelis nr. 2454. - (6) Achelis nr. 2716. - (7) Achelis nr. 2842. - (8) Achelis nr. 3963. (9) Achelis nr. 3087. - (10) Achelis nr. 3112a. - (11) Achelis nr. 3192. - (12) Achelis nr. $3^{8} 3$ I. - (13) Achelis nr. 3737. - (14) Achelis nr. $3^{8} 46$. - (15) Achelis nr. 3970. 


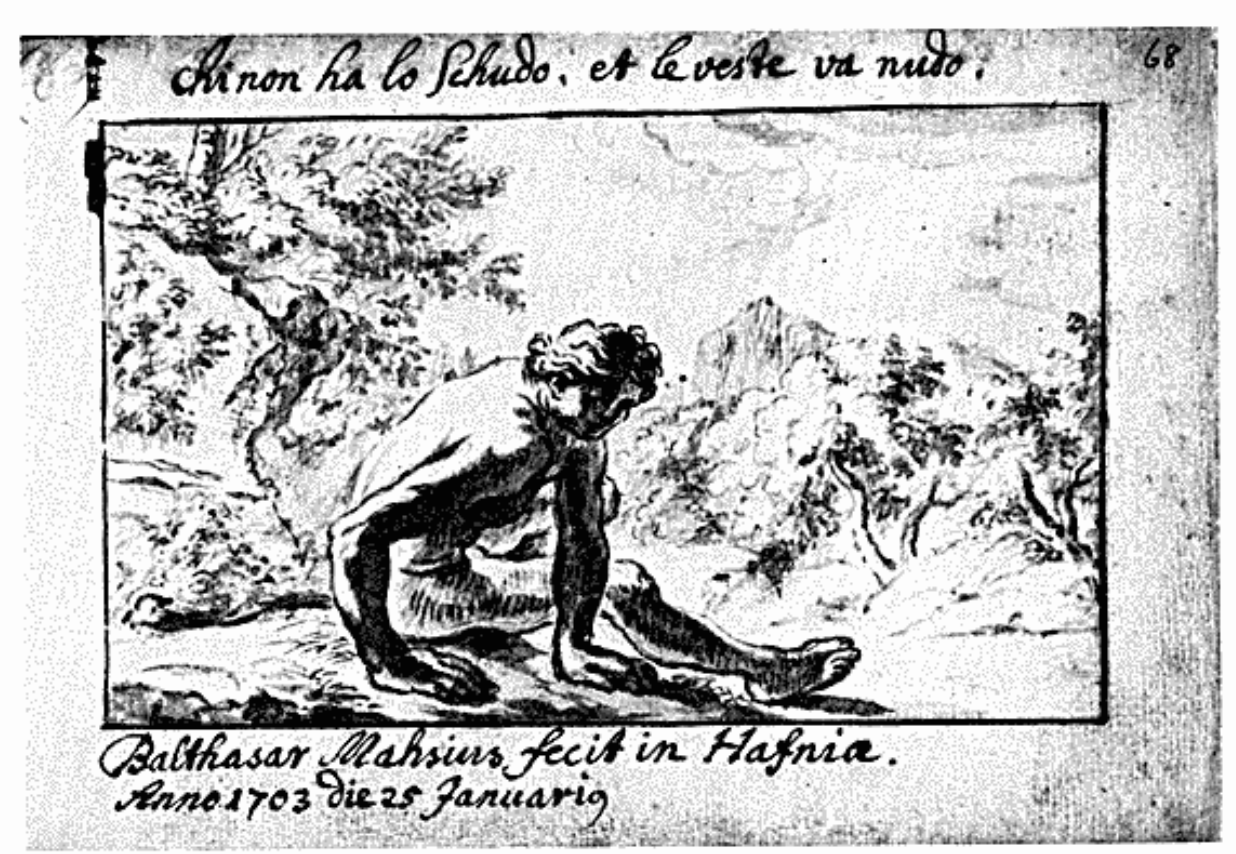

Laveret tegning af maleren Balthasar Masius, dateret Kobenhavn 25.1.1703, i den slesvigske maler N. C. Moritz' stambog. Overskriften: Den som ikke har penge og tøj må gå nogen. Thott $5698^{\circ}$. Lidt formindsket.

\section{Appendiks: Oversigt over ejere af stamboger og stambogsblade} fra tiden $165_{1-1750} i \mathrm{Kgl}$. Bibl.

Oversigten er udarbejdet efter samme retningslinier som oversigterne i F \& F XXI, I974, s. 36-44 og F \& F XXII, I975-76, s. 39-88. Anonyme stambogsejere anfores til sidst $\mathrm{i}$ alfabetet.

I. Ambders, Nicolaus Bernhard, fra Burkal, kollegiesekretær, justitsråd, $\dagger$ 1763. 121 indforsler $1726-37$ fra Greifswald, Leipzig, Halle, Jena, Helmstedt, Hamburg, København, Wien, Paris o.a.st. Indklæbet stambogsblade med indforsler af Philipp Melanchton d. y. I6oI, Hugo Grotius, Hamburg I633, og Hermann Conring, Helmstedt i64o (den sidste til Andreas Ambders, sml. F \& F XXII, s. 7of.), desuden et blad med indforsler fra Wittenberg 1678 og København 1686 (måske til Bernhard Lassæus, se denne). Med register - Thott $549,8^{\circ}$.

2. Axen, Johan Adolph, fra Slesvig, advokat, $\dagger$ efter 1 71 2. Stambogsblade ca. 1692-97 fra Kiel, Frankfurt a.d.O., Berlin, Leipzig, Wittenberg, Halle, Utrecht, London og Oxford i Thott $500,2^{\circ}$ og Thott $1059,2^{\circ}$. 